\title{
A Revision of the Genus Cordyceps.
}

\author{
BY
}

GEORGE MASSEE,

Principal Assistant (Cryptogams), Royal Herbarium, Kew.

\section{With Plates I and II.}

THE genus Cordyceps is of special interest, alike to the mycologist and entomologist, on account of the species being parasitic on insects. The peculiar combination of plant and animal has attracted attention from early times, and has given origin to some remarkable ideas as to the assumed medicinal value of such unusual productions. The historical and romantic side of the subject has been dealt with quite recently by Dr. Cooke ${ }^{1}$. Saccardo ${ }^{2}$ has collected diagnoses of fifty-nine species, including three which are excluded in the present work: of these, seventeen are arranged under species imperfecte cognitae, and even in the case of many not included in the imperfectly described batch, the specific characters are too brief to ensure certainty of determination. In the majority of instances, this imperfection is not due to the absence of type or authentic specimens, but to the fact that a considerable number were described

1 Vegetable wasps and plant worms; S. P. C. K., London (1892).

${ }^{2}$ Sylloge Fungorum, Vol. ii, p. 566, and Vol. ix, suppl.

[Annals of Botany, Vol. IX. No. XXXIII. March, 1895.] 
many years ago, before microscopic detail was considered to be an important factor in the discrimination of species, and up to now, these imperfect diagnoses have not been revised. The determination of a very fine species, recently received from Australia, suggested the necessity of a revision of the genus, and the following is an attempt in this direction, so far as practicable from an examination of the rich collection in the Kew herbarium.

\section{MORPHOLOGY.}

A characteristic feature of the genus Cordyceps consists in the fact that the ascigerous condition always springs from a sclerotium, formed within the body of the insect on which the fungus is parasitic. In those instances where a conidial form is known, as in $C$. militaris, the sclerotium is present before the ascigerous phase appears, but is not so compact in texture, and has not so completely destroyed the internal organs of the host at this period as when the ascigerous condition is developed. The conidial and ascigerous conditions are not met with at the same period, and it is probable that a considerable interval elapses between the appearance of the two phases; a condition of things that would account for the ascigerous stage not immediately following the formation of conidia in artificial cultures.

When fully developed, the sclerotium has completely destroyed and replaced the internal structure of the larva on which it is parasitic, the skin alone remaining intact; structurally it consists of very compactly interwoven hyaline branched septate hyphae, replete with glycogen and minute oleaginous highly refractive globules; when dry it is very compact and hard, and of a whitish colour.

The ascigerous condition usually emerges from the sclerotium at a point between two segments of the skin of the host, and most frequently in the cervical region; it consists of an erect stem-like sterile portion, composed of a fascicle of irregularly parallel septate hyphae, white internally, the 
external or cortical hyphae being usually tinged with colour, and in many species giving off numerous short lateral branches, which form the minutely velvety or downy exterior of the stem. The fertile portion, described in systematic works as the 'head ' or 'club,' is usually terminal on the stemlike sterile stroma, and varies in form in different species from globose to clavate or cylindrical; in some few species the fertile portion is situated below the apex of the stem, or several fertile branches spring laterally from the upper portion of the stem. In structure the ascigerous portion, like the stem, may be composed of more or less parallel septate hyphae; not unfrequently the hyphae coalesce laterally and the compound cells are of various lengths, but much of the hyphal origin is still evident; in a few species the coalescence of the hyphae is complete on all sides, and the septa more numerous, so that the component cells present a polygonal outline irrespective of the direction in which the section is taken, and consequently resemble a true parenchymatous tissue.

The perithecia always originate deep in the stroma, and stand side by side, their mouths reaching the surface of the stroma. In form the perithecia are ovate or flask-shaped, and may remain completely immersed, or at maturity be quite superficial, the whole of the perithecium being exposed, and attached to the stroma by the extreme base; transitional stages connect the two extremes. As a rule, when the perithecia are more or less free from the stroma, the surface of the head is rough, whereas when they are completely immersed, it is smooth; but a section is always necessary in cases where the surface of the head is smooth, as in some species where the perithecia are entirely superficial, only very slightly narrowed at the mouth, and closely crowded, they form an almost even surface, as if immersed.

The asci always contain eight spores, are very long and slender, have a slight swelling at the apex, and are hence described as capitate. The function of the capitate apex is to effect dehiscence when the spores are mature; at this 
stage the contents of the head become swollen and the wall of the ascus is ruptured at the apex (P1. I, Fig. 4).

The spores are almost as long as the ascus, and are arranged in a parallel fascicle which is slightly twisted on its axis, hyaline, very slender, multiseptate, rarely with few septa, or continuous; and after escaping from the ascus the multiseptate ones usually break up readily into their component cells.

Paraphyses are entirely absent.

The forms of Isaria, included at present in the Hyphomycetes, are supposed to be the conidial stage of species of Cordyceps, and in some instances there would appear to be little or no doubt on this point, although it has not been definitely proved by cultures in a single instance. Tulasne ${ }^{1}$ has shown, from the evidence afforded by contiguity of development, that Isaria farinosa, Fr., is the conidial condition of Cordyceps militaris, Link. Atkinson ${ }^{2}$ has recently studied the development of Isaria farinosa, Fr., in artificial cultures, and although some very interesting results were obtained, the ascigerous condition was not produced. The author concludes as follows: "Several cultures on artificial media in culture-tubes have been made, but in no case has anything resulted which shows the perfect or ascigerous stage of the fungus. Upon nutrient agar, nutrient gelatine, and beanstems, nothing but the cottony or fluffy growth, covered by the farinaceous fructification, appears. On potato this growth first appears, to be succeeded by the characteristic fructification of the Isaria-stage. The fact that the Isaria-stage will develop readily on various media such as described above, is evidence that it can develop readily as a saprophyte, and is thus more likely to be preserved in greater abundance and in wider distribution than if it were able to propagate itself only on insects.'

1 Note sur les Isaria et Sphaeria entomogènes; Ann. Sci. Nat. Bot., sér. iv, Vol. viii, p. 35 (1857); also, Torrubia militaris, Sel. Fung. Carpol., Vol. iii, Pl. I, Figs. I9-3I (I865).

${ }^{2}$ Artificial cultures of an entomogenous fungus; Bot. Gaz., Vol. xix, p. I29, Pl. XIV-XVI (1894). 
The fact that Isaria farinosa can develop its characteristic fructification as a saprophyte on other than on insect substratum, demolishes the argument that those so-called species of Isaria not occurring on insects cannot be the conidial of species of Cordyceps.

Numerous species of Cordyceps have no correlated conidial form, and on the other hand, still more numerous forms of Isaria exist, which at present are not suspected of being connected with any known species of Cordyceps. Among the latter may be mentioned more especially Isaria densa, Fries, which has been brought into such prominence by the admirable researches of Giard ${ }^{1}$. This fungus is parasitic on the larva of the cockchafer, known in different parts of France as vers blancs, turcs, mans, \&c., and is well known as one of the most serious of insect scourges with which French agriculturists have to deal. Giard has clearly demonstrated, after years of patient research in the laboratory and in the field, that the conidia of Isaria densa can be utilized under certain conditions as an inoculation-medium, resulting in the wholesale destruction of the larvae.

The form-species of Isaria which can with the greatest amount of probability be considered as conidial conditions of species of Cordyceps, assume different forms of development, as shown by Atkinson and Giard, frequently appearing first as an effused, more or less velvety or cottony layerthe Botrytis-form,- -and afterwards, influenced by unknown conditions, passing on to the more complex, erect or stipitate form known as Isaria; during this phase of development the scierotium is formed within the body of the host, and finally the ascigerous form appears. Numerous species belonging to the form-genus Isaria are only known at present as saprophytes, growing on dead and usually more or less decomposed wood, bark, leaves, flowers, \&c. ; others are met with on decaying fungi or on dung; on the other hand, some species,

\footnotetext{
${ }^{1}$ L' Isaria densa (Link) Fries, Champignon parasite du Hanneton commun (Melolontha vulgaris L.); Bull. Scient. de la France et de la Belg., Tom. XXIV, pp. I-I I2, 4 pl. (I893).
} 
as Isaria fuciformis, Berk., occur as true parasites under certain conditions, although usually developing as saprophytes, thus leading up to such truly facultative parasites as Isaria farinosa, the conidial state of Cordyceps militaris, and Isaria densa, which Giard has some reason for suspecting to be the conidial condition of Cordyceps entomorrhiza.

The genus Hypocrea-as understood in the broader sensemay be looked upon as the type of a number of genera, characterized as such more by the amount of faculative parasitism acquired by their respective conidial forms, than by any strictly morphological characters. The majority of species included in the genus Hypocrea are undoubtedly true saprophytes throughout the cycle of their development; at the same time, some exotic species, whose life-history is unknown, occur on a vegetable matrix which from appearances suggests parasitism, and in the case of certain species occurring on coriaceous leaves, there appears to be very little room for doubt on this point. Epichloë, an allied genus, is mainly characterized by having both the conidial and ascigerous condition developed in the form of a sessile, effused stroma on the culms of living graminaceous plants. In the genus Claviceps, parasitic on the fruits of graminaceous plants, we have a higher stage of development; a conidial condition first appears, followed by the formation of a compact, external sclerotium, which after a period of rest, produces the highly differentiated, stipitate ascigerous form of fruit. It remains to be explained why the members of the two genera last mentioned confine their attacks to plants belonging to the order Gramineae. Cordyceps differs mainly from the last-named genus in being parasitic on insects, and in the sclerotium being formed within the body of the host; the additional character of the spores breaking up into their component cells, as given by Saccardo ${ }^{1}$, being of no value, inasmuch as the spores of some species of Cordyceps are continuous, as in Claviceps. The ascigerous condition of the 


\section{the Genus Cordyceps.}

species of Cordylia is morphologically identical with that of Cordyceps; the generic distinction turns on the absence of a true, compact sclerotium, and in being parasitic on subterranean species of fungi. Finally, the genus Corallomyces is in absolute morphological agreement with the ascigerous portion of those species of Cordyceps having large superficial perithecia, but differs in the absence of a sclerotium, and in being a true saprophyte.

The numerous forms of Isaria having no associated ascigerous stage have not been dealt with.

\section{Hosts.}

As defined in the present work, all the species of Cordyceps grow on insects, and have been recorded as occurring on representatives of the following Orders : Hemiptera, Diptera, Lepidoptera, Hymenoptera, and Coleoptera. The larval condition of the insect is the most frequent host, especially such as bury themselves in the ground or amongst moss or vegetable débris, but different species occur on every stage of insect development; fewest being known to occur on the adult or imago condition, which however is by no means exempt from attack. Our knowledge respecting the various hosts is very incomplete, owing to their being in many instances beyond certain recognition when the fungus shows itself ; and again, until recently it was considered sufficient to state that the fungus was parasitic on a chrysalis, caterpillar, moth, \&c.

Gray ${ }^{1}$ appears to have been among the first to attempt a determination of the various insects attacked by parasitic fungi, and to his researches we are indebted for the determination of certain hosts given under their respective parasites. The hosts are also enumerated, so far as determinable, in the excellent 'Host-Index' by Farlow and Seymour ${ }^{2}$.

1 Notices of insects which are known to form the bases of fungoid parasites. A Memoir, privately printed. London $\left(I_{8} 5^{8}\right)$.

2 A Provisional Host-Index of the Fungi of the United States (1890-91). 
The species of Cordyceps are spoken of as parasites, because it is known that in several instances the fungus attacks the insect while still alive; and in all probability this condition of things is the rule, although the fruiting stage may not be developed until after the death of the host.

\section{DiSTRIBUTION.}

The genus is cosmopolitan, being best represented in temperate regions. Taking into consideration only the fiftyone fully described species, their distribution is as follows :-

Old world . . . 27 species.

New world . . 29 species.

There are 22 species peculiar to the Old World, and 23 species peculiar to the New World, distributed as follows :-

\section{Old World.}

Europe, 8 species.

Asia, Africa, 5 "

Australasia, 6 " (Only I additional species recorded.) East Indies, 2 "

Nere World.

North America, 9 species. (All from the United States.) West Indies, 4 " South America, 8 "

Six species are common to the Old and New World, viz. C. clavulata, C. myrmecophila, C. entomorrhiza, C. militaris, C. sphingum, C. armeniaca: all British except the last named.

C. entomorrhiza has the widest distribution of any known species, being recorded from Europe, Asia, Africa, United States, Australia, and New Zealand.

The Australasian species are remarkable for their gigantic size, as indeed are also the larvae on which they are parasitic. C. entomorrhiza is the only species found in this region that is not peculiar to it. 


\section{ClassificATION.}

From what has already been said relating to the structure and affinities of the genus under consideration, it is evident that two distinct factors-morphological and biological-are available as affording the basis of a systematic arrangement. If grouped from a morphological stand-point, the genera Cordylia, Claviceps, and Corallomyces, at least, would be absorbed in the older genus Cordyceps; this would necessitate the formation of subgenera, which are objectionable from every point of view; hence the biological character is here preferred, as limiting Cordyceps to those species parasitic on insects, the ascigerous condition arising from a sclerotium formed within the body of the host.

\section{CORDyceps, Fries (emended).}

Entomogenous. Conidial state forming an effused downy weft, or an erect, clavate, simple or variously branched stroma, consisting of loosely compacted hyphae, which bear the hyaline, continuous, minute conidia at the tips of short branchlets. Ascigerous stage springing from a compact sclerotium formed within the body of the host; stroma differentiated into an erect stem-like, simple or branched, sterile portion, which bears at its apex the fleshy, globose or elongated ascigerous portion; rarely the sterile axis is continued above the ascigerous part, or several elongated fertile branches spring laterally from the erect, sterile stroma. Perithecia ovate or flask-shaped, either entirely immersed in the fleshy stroma, partly immersed, or quite superficial; asci very long, narrowly cylindric-clavate, slightly constricted just below the capitate apex, narrowed downwards into a long, slender base, 8 -spored, not becoming blue with iodine; spores almost as long as the ascus, filiform, the apical third often slightly thickest, multiseptate, rarely continuous, hyaline, arranged in a parallel fascicle; more or less flexuous when free, and often breaking up into their component cells; paraphyses absent. 
Cordyceps, Fries, Syst. Myc. ii, p. 323 (1823). Used as the name of a tribe of the Pyrenomycetes, including species at present included in the genera Cordyceps and Xylaria.Sacc., Syll. vol. ii, p. 566 (excluding the species parasitic on fungi, which constitute the genus Cordylia, suggested by Tulasne-Sel. Fung. Carp. iii, p. 20).

Tormbia, Lév. The first mention of this name appears to be in Ann. Sci. Nat. ser. 3, p. 43, vol. xx (I853), where Tulasne refers to it in a footnote as follows: 'Torrubia, Lév. (msc. in Herb. Mus. Paris).' The genus is first defined by Tulasne-Sel. Fung. Carp. iii, p. 4 (I 86.5).

\section{* Perithecia entirely or partly immersed.}

\section{$\dagger$ Spores septate.}

1. Cordyceps Barnesii, Thwaites, Fungi of Ceylon, no. 977, in Linn. Soc. Journ., Bot., vol. xiv, p. 110 (1875); Sacc., Syll. ii, no. 5052. (Plate II, Figs. 19-26.)

Stem cylindrical or slightly thickened at the base, minutely velvety, brown, $3-5 \mathrm{~cm}$. long, $2 \mathrm{~mm}$. thick, often flexuous or angularly crooked, simple or rarely forked; head $\mathrm{I}-2 \mathrm{~cm}$. long, 3-4 mm. thick, simple, apex acute, smooth, dotted with the mouths of the densely crowded perithecia when seen under a pocket-lens, $2-3 \mathrm{~mm}$. at the acute apex usually but not always sterile; asci cylindrical, apex capitate, base narrowed into a short pedicel, 8 -spored; spores arranged in a parallel fascicle in the ascus, hyaline, filiform, straight or slightly curved when free, 3 -septate, $120 \times 2 \mu$, readily breaking up into the four component cells which are slightly rounded at the ends, $30 \mu$ long.

Conidial stage. Several of the specimens have the head covered with conidial-bearing branches instead of perithecia ; these branches are erumpent, like the perithecia, and towards the base of the head are slender, very irregularly branched, about $.5 \mathrm{~mm}$. thick, white, each branchlet bearing at its apex a globose or piriform head, about $\mathrm{I}-\mathrm{I} \cdot 5 \mathrm{~mm}$. across, which is densely covered with minute, hyaline conidia, $2 \times 1 \mu$ diameter. The branches become shorter and less branched higher up the 
head, while at the apex they are short and unbranched, bearing a single head at the apex, but this is probably only due to their being younger, the development of the branches being acropetal. The branches consist of very slender hyphae running parallel to the long axis of growth, and expanding like a brush to form the apical head, each hypha bearing a chain of conidia at its tip, the terminal ones becoming free. So far as I can ascertain from the material at hand, the perithecia follow the conidial development on the same head, but on this point I am not certain.

Ceylon (Thwaites, no. I 120 with sketch).

Thwaites' note accompanying the specimens runs as follows. 'Peradeniya, Dec. I 868. Parasitic upon the larvae of a lamellicorn insect (one of the Melolonthidae), which feeds upon the young roots of coffee and other plants. No. I I 20. Please call this Cordiceps Barnesii, B. and Br., after my friend E. H. Barnes, Esq., who first directed my attention to it.'

The specimen from Ceylon, 'on larvae of some lamellicorn insect at the roots of coffee-trees, Bolagodde,' (Thwaites), and referred by Berkeley to Cordyceps sobolifera, Fungi of Ceylon, no. 978, proves to be Cordyceps Barnesii; hence there is no proof of the extension of $C$. sobolifera from its Western home to Ceylon.

2. Cordyceps palustris, Berk., Journ. Linn. Soc., vol. i, p. I 59, tab. I (1857); Sacc. Syll. ii, no. 5018 ; Ellis \& Everh., N. Amer. Pyrenom. p. 6I. (Plate II, Figs. I-6.)

Stem I-3 cm. high, 3-4 mm. thick, simple or divided into 2-4 short branchlets, even, glabrous, brown; ascigerous portion I-2 cm. long, wider than the stem, obtusely cylindric-ovate, dull brownish-purple or flesh-colour, minutely rough with the slightly projecting mouths of the perithecia ; asci elongated, narrowly cylindrical capitate, tapering below into a long, slender pedicel, 8-spored; spores arranged in a parallel fascicle, slightly curved, filiform, ends narrowed, hyaline, multiguttulate, then multiseptate, septa thick, $100-120 \times 1 \mu$, component cells $\mathrm{I} \cdot 5 \mu$ long. 
On moist, putrid logs, growing singly from the larva of some coleopterous insect. On Hexapoda, sp. indet. (HostIndex, p. 182).

Northampton Swamp, S. Carolina, May. (Ravenel, no. 7 I8).

Type specimen, in Herb. Kew., examined.

The perithecia are cylindrical, narrowed at the base when mature, and in reality quite superficial, but owing to being densely crowded and the mouths somewhat obtuse, they appear, when examined with a pocket-lens, to be almost completely immersed in the substance of the stroma. The spores are at first filled with highly refractive oil-globules, and afterwards become multiseptate. I have not seen the spores break up into their component cells, and Berkeley did not intend to convey this idea, as interpreted by Saccardo and Ellis, but meant that the contents became broken up by septa into small parts. Iodine does not colour the asci blue.

3. Cordyceps insignis, Cke. and Rav., Grev. vol. I 2, p. $3^{8}$ (I883); Cooke, Veg. Wasps and Plant Worms, p. I 70, pl. I, fig. 3 ; Sacc., Syll. Suppl. v. ix, no. 4002; Ellis and Everh., N. Amer. Pyren. p. 63.

Stem 3-4 cm. long, $\frac{3}{4} \mathrm{~cm}$. thick, equal, pallid, sulcate (obviously due to shrinkage during drying), very minutely velvety at the base ; head broadly ovate, livid purple (when dry), I. 5 and $\mathrm{I} \mathrm{cm}$., very slightly scabrid from the mouths of the narrowly ovate, completely immersed perithecia; asci narrowly cylindrical, slightly constricted below the capitate apex, narrowed below into a slender, stem-like base, 8-spored ; spores arranged in a parallel fascicle slightly twisted on its axis, hyaline, filiform, multiseptate, wavy when free, $170-180$ $\times \mathrm{I} \cdot 5 \mu$, component cells $6-7 \mu$ long, separating readily at maturity.

On larvae buried in the ground. S. Carolina (Ravenel, no. 325I). On Hexapoda, sp. indet. (Host-Index, p. I 82).

Ravenel's label accompanying the specimen is as follows: 'I found but a single specimen of this and have divided the 
stipe and capitulum, retaining half. I send the whole of the large larva. The colour is pretty well preserved. I have seen several insect Cordyceps here, but this differs from anything I have seen. On dead larva buried in ground. Seabord of S. C., April ı 88ı. H. W. Ravenel.'

Type specimen in Herb. Kew.

Cooke, in describing the present species, says the asci are $600 \mu$ long, and the spores $450 \mu$ long, component cells i $2 \mu$ long. These measurements are wrong, being much too large, and probably due to a mistake as to the objective used during examination. The asci in reality measure $200-225 \times 7-8 \mu$.

4. Cordyceps Puiggarii, Speg., Fung. Fueg. no. 304, in Bol. Acad. Nacional Cord. I 888 ; Sacc., Syll. Suppl., vol. ix, no. 4010.

5. Cordyceps alutacea, Quélet, Champ. Jura et Vosges, in Mém. Soc. d'Emulat. de Montbéliard, 1875, p. 57 ; Sacc., Syll. ii, no. 5023 .

Growing among the leaves of Pinus sylvestris.

Distrib.-France.

In a footnote Quélet says that in texture and fructification this species closely approaches the genus Hypocrea.

6. Cordyceps sobolifera, Berk. and Broome, Fungi of Ceylon, no. 978 ; Sacc., Syll. no. 5021.

Clavaria sobolifera, Hill, Watson and Hill in Phil. Trans., vol. 53, p. 27I, tab. 23 (I 763).

Sphaeria sobolifera, Berk., Lond. Journ. Bot. vol. ii, p. 207 (1843).

Torrubia sobolifera, Tulasne, Sel. Fung. Carp. iii, p. Io, t. I, figs, 32, 33 .

On the larva of a beetle, probable one of the Melolonthidae. Distrib.-Dominica; Martinique; Guadaloupe; S. America, with a note on label, as follows: 'On a larva which destroys the cotton crop in S. America.'

7. Cordyceps sphaecocephala (K1.). Cordyceps sphecophila, Berk. and Curt., Fung. Cub. no. 
751, in Linn. Soc. Journ., Bot., vol. x, p. 376 (1869) ; Sacc., Syll. ii, no. 5015 .

Torrubia sphecocephala, Tul., Carpol. iii, p. I6, t. I, figs. 5-9 ( 1865$)$.

Sphaeria sphecocephala, Klotzsch, in Herb. Hook., Kew ; this name is adopted by Berkeley-On some Entomogenous Sphaeriae; Lond. Journ. Bot., vol. ii, p. 205 (1843)-with the following explanation: "The name given to it by Klotzsch with the authority of Künze attached to it, is clearly a wrong transcription of Künze's name in Myc. Hefte, for a somewhat analogous form of Sp.militaris; viz. S. sphaerocephala. It is, however, so good that I have retained it.'

The word sphecophila was introduced by Berkeley in his mention of the species in Fung. Cuben., no. 75I, presumably by mistake, and this name has been taken up by SaccardoSyll. ii, no. 5015 .

Exsicc.-Fung. Cubens. Wrightiani, no. 75I.

Parasitic on wasps. - species of Vespa and Polybia.

Distrib.-Jamaica (Dr. Bancroft); Cuba (Wright); St. Vincent, collector not noted; Brazil (Glaziou, no. I8778 a).

8. Cordyceps myrmecophila, Cesati, in Klotzsch, Herb. Myc., no. I033 (1846); Cesati, Comm, Critt. Ital. i, p. 6I, t. iv, fig. ii (I86I) ; Nyl., Obs. Pez. Fenn. p. 88, pl. ii, fig. 4 (I868).

Exsicc.-Klotzsch, Herb. Myc. Ed. nova, cura Rabenh. Ed. i, no. 1033 ; Ed. ii, no. 719 ; Rab.-Winter, Fung. Eur. no. 3649 .

Growing on Formica rufa, also on undetermined species belonging to the Coleoptera and Hymenoptera.

Distrib.-Britain ; Finland ; Italy ; Switzerland ; U. States ; Brazil ; Ceylon; Borneo.

9. Cordyceps curculionum, Sacc., Mich. i. p. 320 (1879); Syll. ii, no. 5013 .

Torrubia curculionum, Tulasne, Carpol. iii, p. 20 (1865).

Parasitic on Heilipus celsus, Schoen.

Near Lima, Peru. 
10. Cordyceps Wallaysii, Westend., Ac. Soc. Bot. Belg., vol. vii, p. 81, fig. 21 (I859); Sacc., Syll. ii, no. 50 I 4.

On the undetermined larva of some insect, attached to grass.

Distrib.-Belgium (Westendorp).

11. Cordyceps cinerea, Sacc., Mich. I, p. 320 (1879), Sacc., Syll. ii, no 5026 .

Torrubia cinerea, Tul. Carpol. i, p. 6I (I86I); iii, p. I6, pl. i, fig. I I (I 865).

Exsicc.-Rabenh., Fung. Eur. no. 1010.

On larvae and perfect insects of species of Carabus.

Distrib.-France; Germany.

12. Cordyceps unilateralis, Sacc., Syll. ii, no. 5027.

Torrubia unilateralis, Tulasne, Carpol. iii, p. I8, pl. I, figs. 3-4 (1865).

Growing on an ant-Atta cephalotus, Fabr.

The specimen described by Tulasne came from Brazil, and a specimen in Kew Herbarium was collected by Professor Trail, F.R.S., in the same country, and growing on the same species of ant.

13. Cordyceps australis, Speg., Fung. Arg. Pug. iv, p. 80, no. 208 ; in Ann. Soc. Cient. Argentina (1880); Sacc. Syll. ii, no. 5028 .

Growing on an ant-Pachycondyla striata.

Apiahy, Brazil (Dr. Puiggari).

14. Cordyceps martialis, Speg., Fung. Puigg, no. 305 ; in Bol. Acad. Sc. Córdova (1889), Sacc., Syll. Suppl. vol. ix, no. 40 II.

On the larva of some member of the Cerambicidae, near decaying stumps.

Distrib.-Apiahy, Brazil.

15. Cordyceps goniophora, Speg., Fung. Puigg., no. 307 ; in Bol. Acad. Cient. Cord. (1889), Sacc., Syll. Suppl. vol. ix, no. 4012. 
On the decayed body of a species of Mutilla; among moss. Distrib.-Apiahy, Brazil.

16. Cordyceps Ditmari, Quélet, Soc. Bot. France, p. 330xxxviii, pl. vi, fig. I4, séance du 22 Oct. 1877 ; Sacc., Syll. no. 5024 .

On wasps and flies.

Distrib.-France; Germany; Ireland.

Quélet says that the fungus called Isaria sphecophila, Ditmar, in Sturm's Deutschl. Flora, iii, p. II5, tab. 57, is the conidial form of the present species, and hence called it Cordyceps Ditmari. I have received a Cordyceps agreeing exactly with Quélet's description, and accompanied by Isaria sphecophila, Ditm. from Ireland, collected by Dr. McWeeney. It was growing on the remains of a large bluebottle-like fly.

17. Cordyceps larvicola, Quél., Bull. Soc. Bot. France, tom. xxv, p. 292, pl. iii, fig. I (1878).

Cordyceps Helopis, Quél., Bull. Soc. Bot. France, tom. xxvi, p. 235 (1879); Sacc., Syll. ii, no. 5025.

On the larva of Helops caraboides, Panz.

Distrib.-France.

The present fungus was first described by Quélet as C. larvicola, growing on some undetermined larva. The year following this the same fungus was collected by Boudier, and its host determined as Helops caraboides, Panz. Thereupon Quélet re-described the fungus, calling it C. Helopis, giving $C$. larvicola as a synonym. The oldest name is restored in the present work.

18. Cordyceps stylophora, Berk. and Broome, Journ. Linn. Soc., Bot., vol. i, p. I58, pl. i (1857); Sacc., Syll. ii, no. 5017 ; Ellis and Everh., N. Amer. Pyren. p. 6I. (Plate II, Figs. 40-42.) Exsicc.-Rav., Fung. Car. Exs., Fasc. v, no. 49.

Solitary; entirely tawny when dry; stem $\mathrm{I} \cdot 5-2.5 \mathrm{~cm}$. high, $\mathrm{I} \cdot 5^{-2} \mathrm{~mm}$. thick, straight or flexuous, velvety or sometimes almost strigose at the base, longitudinally wrinkled when dry; head cylindrical, I-I.5 $\mathrm{cm}$. long, $2.5-3 \mathrm{~mm}$. thick, almost 
smooth, marked with minute depressions corresponding to the mouths of the immersed, scattered perithecia; the apex of the head runs out into a slender, pointed, sterile, spine-like prolongation $\mathrm{I}-\mathrm{I} \cdot 5 \mathrm{~cm}$. long; asci cylindrical, very slightly narrowed below the slightly capitate apex, 8-spored; spores arranged in a parallel fascicle in the ascus, hyaline, filiform, slightly curved when free, multiseptate, $125^{-1} 35 \times$ I $\mu$, the component cells about $3.5 \mu$ long.

On Hexapoda, sp. indet. (Host-Index, p. I82). On larvae buried in rotten logs. South Carolina (Ravenel, no. 1325).

Type specimen in Herb. Kew., examined.

A remarkable species, characterized by the long, slender, sterile apiculus, continuing beyond the apex of the fertile head; or in other words, the fertile portion-head-occupies about the median third of the stem. This character appears to be constant, being present in each of the eight specimens sent by Ravenel to Berkeley, several being fertile and in a fine state of preservation. The specimens in Ravenel's Exsicc. are poor and scanty.

19. Cordyceps gentilis, Sacc., Syll. ii, no. 5020 .

Torrubia gentilis, Cesati, Myc. Borneo, in Mem. Acad. Neapol. p. I 4 (I879).

Growing on a wasp.

Distrib.-Sarawak, Borneo (Beccari).

20. Cordyceps Hawkesii, Gray. Notices insect bases of fungi, pl. v, figs. IO-I2 (1858); Grev. vol. xix, p. 76 ; Sacc., Syll. Suppl. vol. ix, no. 40 I 3 .

' The caterpillar may be that of a species of Pielus, or of some closely allied genus.'

Distrib.-Tasmania (Hawkes).

21. Cordyceps Forquignoni, Quél., xvi Suppl. Champ. Jura et Vosges, p. 6, t. 2I, fig. I.8; Sacc., Syll. Suppl. ix, no 4007.

On Musca rufa or Dasyphora pratorum.

Distrib.--France. 
22. Cordyceps Barberi, Giard, Compt. Rendus Soc. de Biol., Paris, séance du 22 Déc. 1894, p. 82.3. (Plate II, Figs. 34-35.)

Gregarious, most numerous in the cervical region, but springing from every part of the caterpillar, 2-4 cm. high, entirely whitish or tinged with amber upwards; ascigerous portion $\frac{1}{3}-\frac{1}{2}$ the whole length, tip pointed, often curved, 3-4 $\mathrm{mm}$. thick at the widest part, smooth and even, very minutely pitted with the mouths of the completely immersed, ovate perithecia ; stem slender, wavy ; asci narrowly cylindricclavate; very slightly narrowed immediately below the capitate apex, 8-spored; spores hyaline, arranged in a parallel, very slightly twisted fascicle in the ascus, filiform, very slightly thickened above the middle, multiguttulate, then multiseptate, I I $5^{-1} 25 \times \mathrm{I} .5 \mu$; component cells about $2.5 \mu$ long.

Parasitic on the larvae of Diatraea saccharalis, Fab., the perfect state of which is known in the West Indies as the ' moth-borer,' on account of its habit of perforating the culms of sugar-cane, and consequently doing a large amount of injury to the crop.

Distrib.-Barbados; Antigua.

Type specimens in Herb. Kew.

The specimens were sent to Kew by Mr. John R. Bovell, F.C.S., F.L.S., \&c., during the autumn of 1894 , and were labelled Cordyceps Bovellii, but C. Barberi, Giard, has been adopted, having priority of publication, and on the assumption that Isaria Barberi, Giard, 1.c., is the conidial form of the ascigerous condition described above.

The larvae are attacked by the fungus while lying in their burrows in the cane-stems. The fungus springs from every part of the caterpillar, hence the stems vary in length, those originating farthest away from the mouth of the burrow being longest, as all the stems appear to grow towards the opening, and push the ascigerous portion into the air.

23. Cordyceps Gunnii, Berk., Decad. Fung. no. 200, in Hook. Journ. Bot., vol. vii, p. 577, pl. xxii (I848); Flor. Tasm. ii, p. 278 ; Curr., Comp. Sphaer., Trans. Linn. Soc. 
vol. xxii, p. 262, t. xlv, figs. I, 2; Cooke, Veget. Wasps and Plant-worms, p. 143, fig. 30 (a small specimen); Sacc., Syll. vol. ii, no. $5 \circ 3 \circ$.

Solitary, springing from the cervical region of the caterpillar on which it is parasitic ; very variable in size, but always large; stem 6-30 cm. long, 5-8 mm. thick, sub-cylindrical, almost even, simple or rarely forked, one branch usually being much smaller than the other, whitish, the greater portion buried in the ground and covered, more or less, with minute particles of sand; ascigerous portion cylindrical or lanceolate, apex acute or obtuse, 4-8 cm. long, somewhat thicker than the stem; even, perithecia narrowly ovate, completely immersed, the crowded mouths projecting as minute points above the surface of the club; asci cylindric-clavate, slightly constricted just below the capitate apex, 8-spored; spores arranged in a parallel fascicle in the ascus, hyaline, filiform, upper portion with a very slight tendency to become clavate, at first multiguttulate, then multiseptate, somewhat wavy when free, $155-165 \times 2-5-3 \mu$; component cells $4-5 \mu$ long, readily. separating at maturity.

On caterpillars of some Cossus or Hepialis.

Franklin Village, near Lancaster; Tasmania (Gunn, no. I800); Melbourne, Victoria (F. Reader); Blue Mountain Range, New South Wales (Rev. D. Wood); Port Philip, Australia (C. French).

Type specimens in Herb. Berk., Kew.

Growing from the neck of a caterpillar buried deeply in sandy ground. Stem with caterpillar five to eighteen inches long, rarely branched, flexuous, rugged below, cylindrical, white, solid, collecting particles of sand by means of a few downy threads. (Gunn in litt.)

24. Cordyceps flavella, Berk. \& Curt., Fungi Cubenses, no. 748 , in Linn. Soc. Journ. vol. x, p. 375 (I869); Sacc., Syll. vol. ii, no. 5022. (Plate II, Figs. 7-10.)

Stems gregarious, 3-5 springing from nearly the same point, $24-30 \mathrm{~mm}$. long, about $\mathrm{I} \mathrm{mm}$. thick, equal, straight or

C 2 
slightly flexuous, even, glabrous; head globose, rough with the projecting mouths of the perithecia, $2 \mathrm{~mm}$. diameter, like the stem pale-yellow; asci elongated, narrowly cylindrical, apex capitate, narrowed below into a slender pedicel, 8-spored; spores arranged in a parallel fascicle, slightly flexuous when free, hyaline, filiform, multiseptate, $80 \times$ I $\mu$, component cells about $4 \mu$ long.

Among leaves on wood, growing from portion of a caterpillar. Cuba (Wright, no. 519).

Perithecia crowded, mouths narrowed and prominent. The entire fungus is pale amber-colour, and the stem is almost translucent when dry.

25. Cordyceps Lloydii, Fawcett, Ann. Nat. Hist., I 886, p. 316, with a fig.; Cooke, Veg. Wasps and Plant Worms, p. 36, with fig.; Sacc., Syll. Suppl. vol. ix, no. 4009.

On the body of an ant-Camponotus atriceps.

Distrib.-Near the river Púruni, Guiana.

26. Cordyceps dipterigena, Berk. \& Broome, Fungi of Ceylon, no. 980, in Linn. Soc. Journ., Bot., vol. xi, p. I I I (187 I); Sacc., Syll. viii, 5053. (Plate II, Figs. 29-32.)

Gregarious; stems simple, $\frac{1}{2}-\mathrm{I} \mathrm{cm}$. high, I mm. thick, cylindrical, smooth and even, pallid, head globose, smooth, pallid, about $3 \mathrm{~mm}$. across; asci cylindrical, narrowed below into a long, slender pedicel, apex capitate, 8-spored; spores arranged in a parallel fascicle in the ascus, hyaline, filiform, multiseptate, slightly constricted at the septa, and apparently always breaking up into the component cells, which are linear-elliptic, ends narrowed, truncate, hyaline, Io $\times \mathrm{I}^{\circ} 5 \mu$, before leaving the ascus.

On dipterous insect. Ceylon (Thwaites).

Type specimen in Herb. Kew., examined.

A very fine and remarkable species, easily recognized by the peculiar structure of the spores. The perithecia are completely immersed in the substance of the stroma, the mouths appearing as very minute depressions on the surface when moist. 
27. Cordyceps bicephala, Berk., Decades of Fungi, no. 617 , in Hook. Journ. Bot., vol. viii, p. 278 (1856); Sacc., Syll. ii, no. 5029. (Plate II, Fig. I6.)

Solitary; stem $5 \mathrm{~cm}$. long, I mm. thick, equal, even, slightly curved at the base, very minutely pulverulent under a lens, brown, paler upwards, forked into two equal branches at $\mathbf{I ~} \mathrm{cm}$. from the apex, each branch terminated by a pale brown, elliptical, perfectly even, minutely pulverulent head measuring $3 \times 2 \mathrm{~mm}$. ; asci cylindrical, narrowed at the base into a long, slender pedicel, apex capitate, 8-spored; spores arranged in a parallel fascicle in the ascus, hyaline, linear, slightly wavy when free, multiseptate, $70 \times \mathrm{I} \mu$; component cells about $3 \mu$ long, not observed to break up at the septa.

Panuré, Rio Negro, S. America (Spruce).

Type specimen in Herb. Kew., examined.

This curious species, of which I have seen a single specimen only, is almost intermediate between Cordyceps and Xylaria, the latter of which it approaches in substance. The clavate tip of the inner membrane of the ascus, and the filiform sporidia, indicate an affinity with the more noble species of Cordyceps (Berk., 1. c.).

As stated by Berkeley, the present species closely resembles superficially certain species of Xylaria, section Xylodactyla; nevertheless it is a genuine Cordyceps. The perithecia are somewhat crowded, and completely immersed in the stroma; hence the surface of the head is perfectly smooth and even when dry, the mouths of the perithecia showing as minute depressions when moist. It is not probable that the apical forking of the stem is a constant specific feature, as in other species the branching is often very erratic. Unfortunately no mention is made of its habitat.

28. Cordyceps velutipes, Mass. (n. sp.). Solitary, or more frequently gregarious, springing from the under surface of the cervical region of a caterpillar; every part ochraceous-brown when dry; stem simple or forked, $2-4 \mathrm{~cm}$. long, 3-4 $\mathrm{mm}$. thick, usually crooked, lower portion densely villose, becoming 
glabrous upwards; head subglobose or broadly ovate, up to I cm. long, smooth and even; perithecia completely immersed, elongated, narrowly cylindric-ovate; asci slender, slightly contracted below the capitate apex, 8 -spored; spores arranged in a parallel fascicle in the ascus, multiseptate, $150-160 \times \mathrm{I} \mu$, not seen free.

'On larva of Elateridae.'

Type in Herb. Kew. ; comm. Prof. MacOwan. 'Klerksdorp, S. Afr. Republ., E. G. Alston.'

29. Cordyceps clavulata, Ellis \& Everh., N. Amer. Pyrenomyc. p. 6I, pl. xv, figs. II-I3 (1892).

Sphaeria clavulata, Schw., Syn. N. Amer. Fungi, in Trans. Amer. Phil. Soc., vol. iv, n. ser. (1834).

Cordyceps pistillariaeformis, Berk. \& Br. no. 969, in Ann. Nat. Hist. ser. iii, vol. 7, p. 13, pl. xvi, fig. 22 (1861); Sacc., Syll. ii, no. 5019 .

Torrubia pistillariaeformis, Cooke, Hdbk. no. $23^{2} 3$ (1871). Ellis, 1. c., says, 'The Syn.' Torrubia cinerea, Ell. 'in Sacc. Syll. rests on some error.' The error originated as follows. Ellis sent a specimen to Cooke, labelled as follows, 'Torrubia cinerea, n. s.-on bark louse, on Clethra alnifolia. Newfield, N. Y., Oct. 1875, J. B. Ellis.' Cooke observing that the specimens were identical with Sphaeria clavulata, Schw., and Cordycepspistillariaeformis, B. \& Br., sent a note to that effect to Saccardo for the Sylloge.

Exsicc.-Roumeg., Fung. Sel. Exs. no. 4782 (as Cordiceps pistillariaeformis, B. \& Br.); Thüm., Myc. Univ. no. 1258 (as Torrubia clavulata, Peck).

On dead scale insects (Lecanium), on living branches of Fraximus and Prinos, N. Y. (Peck). On branches of Clethra, Newfield, N. Y., on Carpinus, Canada (Dearness) (Ellis \& Everh., 1. c.).

Berkeley's British specimens, now in Kew Herbarium, are growing on some scale-insect on Wych-elm (Ulmus montana), and agree in every detail with the American species.

Distrib.-United States ; Canada ; Great Britain. 
30. Cordyceps armeniaca, Berk. \& Curt., Journ. Linn. Soc., vol. i, p. 158 , tab. i (1 857$)$; Sacc., Syll. ii, no. 5016 ; Ellis and Everh., N. Amer. Pyrenom. p. 6o. (Plate II, Fig. I8.)

Stem 5-9 $\mathrm{mm}$. high, up to I $\mathrm{mm}$. thick, equal, glabrous, often flexuous and sometimes twisted, pale orange with a tinge of pink; ascigerous portion subglobose, $2-3 \mathrm{~mm}$. diameter, apricot colour, rough with the slightly projecting mouths of the perithecia; asci elongated, narrowly cylindric-clavate, capitate, tapering below into a long, slender pedicel, 8 -spored ; spores arranged in a parallel fascicle, slightly curved or flexuous when free, filiform, ends narrowed, hyaline; multiguttulate, then multiseptate, $80-85 \times$ I $\mu$, breaking up into its component cells, which are about $3 \mu$ long.

Apparently on the excrement of birds. Society Hill, South Carolina (Ravenel, 3774); Rangoon (Capt. E. S. Berkeley); Ceylon, on coleopterous insect (Thwaites).

Type specimen in Herb. Kew., examined.

The specimens are solitary or 2-3 springing from nearly the same point. Perithecia ovate, densely crowded; ostiolum narrowed and somewhat elongated when moist, more or less contracted when dry, so that the head is only slightly rough.

31. Cordyceps caloceroides, Berk. \& Curt., Fungi Cubenses, no. 749, in Linn. Soc. Journ., Bot., vol. x, p. 375 (1869) ; Sacc., Syll. ii, no. 5050. (Plate II, Figs. I I-I3.)

Stem 8-9 cm. high, dividing about half way up into two equal branches, smooth, even, shining, reddish-brown, about $1 \frac{1}{2} \mathrm{~mm}$. thick below the bifurcation, branches thinner, cylindrical, more or less flexuous, base curved; each branch is terminated by an elongated, narrowly cylindrical, acute head coloured like the stem, and minutely rough with the projecting mouths of the crowded perithecia, $3-5 \mathrm{~cm}$. long; asci narrowly cylindrical, apex slightly capitate, base narrowed into a long slender pedicel, 8-spored ; spores arranged in a parallel fascicle in the ascus, hyaline, filiform, slightly curved when free, $75^{-80}$ $\times$ I $\mu$, multiseptate, component cells $4-5 \mu$ long. 
On the ground. Cuba (Wright, no. 3og).

Type specimen in Herb. Kew., examined.

No mention is made of the habitat, and the base of the stem is quite naked. The perithecia are perfectly superficial, but closely crowded, the narrowed mouths giving the superficial granular appearance to the head when seen under a pocket-lens. The structures of the head and walls of the perithecia are truly parenchymatous.

32. Cordyceps sinensis, (Berk.) Sacc., Syll. ii, no. 5051 .

Sphaeria sinensis, Berk., Lond. Journ. Bot., vol. ii, p. 207, tab. viii, fig. I (1843). (Plate II, Fig. I7.)

Solitary ; stem $2.5-5 \mathrm{~cm}$. long, 2-3 $\mathrm{mm}$. thick, almost cylindrical, or sometimes becoming thicker downwards, straight or flexuous, more or less downy at the base, longitudinally wrinkled when dry; head cylindrical, apex pointed and usually-but not always-sterile, $\mathrm{I}-2 \cdot 5 \mathrm{~cm}$. long, 3-4 $\mathrm{mm}$. thick, surface minutely granular with the slightly projecting, obtuse mouths of the ovate, slightly distant perithecia; asci cylindrical, very slightly narrowed just below the capitate apex, base narrowed into a slender pedicel, 8-spored; spores arranged in a parallel fascicle in the ascus, hyaline, filiform, slightly flexuous when free, multiseptate, $85^{-90} \times \mathrm{I} \cdot 5 \mu$, component cells about $4 \mu$ long, not observed to separate.

Growing from the head of a caterpillar, which GrayNotices of Insects which are known to form the bases of Fungoid Parasites, p. I 2-considers as belonging to the Noctuidae, and probably to the genus Gortyna.

China. Also stated to occur in Japan and Thibet.

Type specimen in Herb. Kew., examined.

In one of the specimens figured by Berkeley the head is shown to be compressed and inclined to branch at the apex. The flattening appears, from examination of the specimen, to be due to shrinkage, being immature and soft when collected.

Accounts mostly of historical interest relating to this species, which is highly prized in China on account of its supposed 
medicinal virtues, are to be found in the following works, under the titles given :-

Hia Tsao Tom Tchom; Réaumur, Mém. de l'Acad. des Sc., 1726 , p. 302, tab. xvi; Rees, Cycl. vol. xvii.

Hia Tsao Tong Tchong; Duhalde, China, vol. iii, p. 490.

Hea Tsaon Taong Chung; Westwood, Ann. Nat. Hist. vol. viii, p. 217 .

Chinese Plant Worm; Cooke, 'Vegetable Wasps and Plant Worms,' p. 200.

The following account is given by Berkeley, following the diagnosis of the species:- "This species is a celebrated drug in the Chinese Pharmacopoeia, but from its rarity only used by the Emperor's physician; in its properties it resembles Ginseng, being a strengthener and restorative, but does not like that cause hemorrhage. Father Perennin states that he was raised from a state of extreme weakness by the use of this medicine, which was administered dressed in the body of a duck. The Chinese name refers to the notion that it is a herb in summer and a worm in winter. It is sold in little bundles tied up with silk.'

33. Cordyceps entomorrhiza, (Dickson) Fries, Summa Veg. Scand. p. $3^{81}$ (I 846) (name only); Sacc., Syll. ii, no. 5012.

Sphaeria entomorrhiza, Dickson, Fasc. Plant. Crypt. Brit., Fasc. i, p. 22, tab. iii, fig. 3 ( 1785 ).

Tormbia entomorrhiza, Tul., Carp. vol. iii, p. 14, pl. i, figs. I 2-1 8 (figures excellent).

Xylaria gracilis, Grev., Scot. Crypt. Fl. p. 86, pl. 86 (1823-1828).

Cordyceps gracilis, Dur. \& Mont., Flor. Alg. i, p. 449; figure in atlas, pl. xxv, fig. ii ; Sacc., Syll. ii, no. 5011.

Cordyceps menesteridis, Müll. \& Berk., Gard. Chron., Decr. 21, I878, fig. I 30 .

The fungus grows on different hosts. Gray says that the larva figured by Dickson may probably belong to the Silphidae, while the specimen figured in his own work, pl. iii. fig. 10, he supposes, judging from the caterpillar, to belong 
to the Lithoosidae. Saccardo-Syll. ii, p. 567-says the fungus occurs on larvae belonging to the genus Tinea. The Australian specimens were found on the larvae of Menesteris laticollis. On Hexapoda, sp. indet. (Host-Index, p. 182). On Melolontha vulgaris-Giard, 1. c., p. 46.

Examination of a specimen of Xylaria gracilis from Greville enables me to reduce that form to the present species. The type of Cordyceps menesteridis also examined.

Exsicc.-Cooke, Fung. Brit. Exs., no. I87; Plowright, Sphaer. Brit., Cent. 2, no. i.

Distrib.-Great Britain (Berkeley, Broome, Cooke, Dickson, Greville, Leighton, Plowright); Germany (Auerswald); France (Bernier); Algiers (com. Montagne); Lower Carolina (Ravenel, no. 2613); New Zealand (Colenso, no. 3015); Australia (Mueller); Khasia (Hooker).

34. Cordyceps herculea, Sacc., Syll. ii, no. 5055; Ellis \& Everh., N. Amer. Pyrenom., p. 63 .

Sphaeria herculea, Schw., Syn. Fung. Amer. Bor. no. I I53, in Trans. Amer. Phil. Soc. vol. iv, n. ser. (1 834).

On Hexapoda, sp. indet. (Host-Index, p. 182).

Distrib.-United States. Salem, N. C. (Schw.); Ohio (Prof. A. P. Morgan).

35. Cordyceps Langloisii, Ellis \& Everh., N. Amer. Pyrenom. p. 62 (1892).

On dead larvae of ' mason-wasp.'

Distrib.-United States, near St. Martinsville, La. (Langlois, no. 229.5).

36. Cordyceps nutans, Pat., Bull. Soc. Myc. 1887, p. 127, pl. xi, fig. 5 ; Sacc., Syll. Suppl. ix, no. 4005 .

Springing from between the head and thorax of some adult hemipterous insect.

Distrib.-Japan.

37. Cordyceps Odyneri, Quél., Bull. Soc. Mycol. 1886, p. 80 ; 14th Suppl. Champ. Jura et Vosges, p. 10, pl. xii, fig. 
28, in Bull. de l'Assoc. Franç. pour l'avancem. des sc., Congrès de Grenoble, I 885 ; Sacc., Syll. Suppl. vol. ix, no. 4006.

On the larva of a species of Odynera.

Distrib.-France.

38. Cordyceps Sherringii, Massee, Annals Bot., vol. v, p. 5 10, fig. 4 (1890); Cooke, Veget. Wasps and Plant Worms, p. 55, fig. 8 (incorrectly written Sheeringii).

Cordyceps Sheeringii, Massee; on an ant.

Growing from a small ant, attached to the living frond of a fern.

Distrib.-Is. of Granada, W. Indies.

\section{†† Spores continuous.}

39. Cordyceps albida, Pat., Bull. Soc. Myc., ı 888, p. i 16 ; Sacc., Syll. Suppl. ix, no. 4004.

On a dead, undetermined larva, buried in sand.

Distrib.-Atures, Venezuela.

40. Cordyceps Doassansii, Pat., Tab. Analyt. Fung., p. 213 , fig. 494 (1885); Sacc., Syll. Suppl. vol. ix, no. 4008.

On chrysalis of Lepidopterous insect.

Distrib.-France.

\section{** Perithecia superficial.}

† Spores septate.

41. Cordyceps Taylori, Sacc., Mich., i, p. 320 (1879); Sacc., Syll. ii, no. 504I ; W. G. Smith, Gard. Chron. Feb. 26, 1887, p. 288, fig. 62 (excellent); Cooke, Veget. Wasps and Plant Worms, p. 155, fig. 3I (being a portion of the fig. from Gard. Chron.).

Sphaeria Taylori, Berk., Hook. Journ. Bot. vol. ii, p. 209, tab. viii, fig. 2 ( 1843$)$.

Sphaeria innominata, Taylor, Tasmanian Journal, 1848 , p. 308 , fig. 2.

Springing from the second joint from the head, stem stout, 
entire at the base where it is $1 \cdot 5^{-2} \mathrm{~cm}$. thick, soon breaking up into 3-5 almost equal branches $5-9 \mathrm{~cm}$. long and $\mathrm{I} \mathrm{cm}$. thick, very rugged and irregular, covered with a dense, reddish-brown tomentum, more or less buried in the ground and covered with particles of earth; the apex of each branch is terminated by the ascigerous portion, which takes the form of a stag's antler, branched, compressed, axils rounded, tips acute, 3-6 cm. high, with a spread of 3-4 cm., the broadest branches up to $\frac{3}{4} \mathrm{~cm}$. in width; $\mathrm{I}-3$ such branches spring from the tip of each stem; these branches are at first minutely velvety and wash-leather colour, becoming glabrous, greyish black, and rough with the superficial, broadly ovate, obtuse perithecia; asci narrowly cylindric-clavate, slightly constricted below the capitate apex, narrowed below into a slender pedicel, 8-spored; spores arranged in a parallel, slightly twisted fascicle, flexuous when free, hyaline, cylindricfiliform, ends attenuated, multiseptate, $150-175 \times 2 \mu$, component cells about $3 \mu$ long.

Growing on some undetermined caterpillar, $12-15 \mathrm{~cm}$. long, buried in black, alluvial soil.

Distrib.-Banks of the Murrambidgee, Australia (Adams; com. Taylor) ; Victoria (Sir F. von Mueller).

The largest and finest species in the genus; specimens in the Kew Herbarium show that the body of the caterpillar is completely filled with the sclerotium before the fungus bursts through to produce its fructification. The sclerotium is very compact, and when dry is as hard as wood, the hyphae forming it are very slender, rarely exceeding $3 \mu$ in thickness, sparsely septate, and very densely interwoven.

42. Cordyceps Henleyae, Mass., Ann. Bot. vol. viii, p. II9. (Plate I.)

Solitary, springing from the cervical region of a large caterpillar, stroma or stem erect $18-20 \mathrm{~cm}$. long and about $\frac{2}{3} \mathrm{~cm}$. thick, cylindrical, slightly narrowed at the base, pale brown, very minutely velvety under a lens, even when fresh, becoming longitudinally wrinkled when dry; fertile branches 
erumpent, springing at intervals from the upper third of the stem, 6-9 in number and arranged in a corymbose manner, $6-10 \mathrm{~cm}$. long, $\frac{1}{2} \mathrm{~cm}$. thick at the widest part, attenuated upwards; perithecia superficial, crowded but distinct, flaskshaped with a long mouth, pale brown; asci narrowly clavate, capitate, narrowed below into a slender pedicel, 8-spored; spores arranged in a parallel fascicle in the ascus, the entire fascicle slightly twisted on its axis, hyaline, linear, ends slightly tapering, multiseptate, I $25^{-1} 30 \times 2 \mu$; component cells $2.5 \mu$ long, readily separating at maturity.

Parasitic on a large caterpillar, apparently the larva of some species of Hepialus.

Owen's River, Victoria, Australia ; coll. Miss M. Henley; comm. Sir Ferd. Mueller.

Type specimen in Herb. Kew.

A very distinct and beautiful species, without any near ally. Judging from the presence of numerous particles of sand adhering to the lower portion of the stem, it may be supposed that the caterpillar was buried several centimetres below the surface. The amount of differentiation is more marked in the present than in any other known species, the fertile branches being quite distinct, and erumpent from the upright stroma or stem. The transverse septa of the spores are thick, and when the spores have once become dry, do not thoroughly expand in water, the cell-wall remaining more contracted than the rigid septa, and presenting the appearance shown in Figs. 5 and 7, Pl. II ; when treated with dilute potassic hydrate the spores assume their original, normal appearance, Figs. 6 and 8, Pl. II. The skin of the caterpillar bearing the fungus is intact, but the whole of the contents with the exception of traces of the alimentary canal have been replaced by a mass of compactly interwoven, branched, sparsely septate, hyaline hyphae, forming a true sclerotium, white in colour, and of a woody hardness when dry.

No trace of a conidial stage, and no external mycelium is present on the specimens. 
43. Cordyceps Hugelii, Corda, Anleit. Stud. der Mycol. p. 207 , tab. F, fig. 22 (I842); Sacc., Syll. ii, no. 5034 .

Sphaeria Hugelii, Corda, Icon. Fung. pt. iv, p. 44, tab. ix, fig. I 29.

Sphaeria Robertsii, Hook., Hook. Journ. Bot. vol. ii, p. 209 ( 1843 ).

Cordyceps Robertsii, Hook., Flor. New Zealand, vol. ii, p. 202 (1855).

Parasitic on the larva of Hepialis virescens, Doubleday.

Distrib.-New Zealand (Colenso; Dr. Berggren; F. Moore). var. neglecta, Mass. (Plate II, Fig. 33.)

Agreeing with the typical form in general appearance and size, also in occurring on the same host; differing in the superficial perithecia being flask-shaped with a long, slender ostiolum, and in the component cells of the spore measuring $6-7 \times 2 \mu$.

New Zealand (Colenso).

Type in Herb. Kew.

44. Cordyceps militaris, Link, Hdbk. iii, p. 347 ( 1833 ); Sacc., Syll. ii, no. 5031 .

Clavaria militaris, Linn., Sp. Pl., ed. i, p. II82 (I753); Flor. Dan. tab. 657 (I775).

Torrubia militaris, Tul., Sel. Fung. Carp., iii, p. 6, t. i, figs. I9-3I.

(Conidial form) Ramaria farinosa, Th. Holm., Nov. Act. Acad. Hafinen., vol. i, p. 299, fig. 6 (178I).

Isaria farinosa, Fries, Syst. Myc. iii, p. 27 I (1832).

Exsicc.-Sydow, Myc. March., no. 954; Klotzsch, Herb. Myc. no. 47 ; Plowright, Cent. iii, no. I, of Sphaer. Brit. ; Fuckel, Fung. Rhen. nos. 1067 and 2535; Rabenh., Winter Fung. Eur. no. 3548 (in larvibus et sphingibus emortuis); Roum., Fung. Gall. Exs. no. 3157.

Growing on the chrysalis or larva stage of insects mostly belonging to the Lepidoptera. Gray mentions Phalera bucephala, one of the Notodontidae, as one of the hosts. On Lachnosterna quercina (Thaxter, Host-Index, p. I 8I). 
According to Giard the ordinary habitat of this species is on the caterpillars of Bombyces belonging to the genus Gastropacha. Has also occurred on the perfect form of the cockchafer (Melolontha vulgaris) according to Roumeguère, Rev. Mycol. vi, p. 150 (I884).

Distrib.-Britain, Germany, France, Italy, Belgium, Norway, Sweden, Finland, Russia, Portugal (Henriquez); United States, South Carolina, Curtis, no. 45I; Alabama, Peters, no. 5245 ; Mt. Eliza, Ceylon (Thwaites, no. 341).

45. Cordyceps typhulaeformis, Berk. \& Cooke, Grev. vol. xii, p. 78 (1883); Sacc., Syll. Suppl., vol. ix, no. 4003 . (Plate II, Fig. I4.)

Gregarious, and springing from a dense felt of yellowish mycelium which partly covers the chrysalis on which the fungi are growing, and extends for some distance up the slender stems, which are about I cm. long; head cylindrical, obtuse, simple or rarely with $\mathrm{I}-2$ branchlets, about $\mathrm{I} \mathrm{cm}$. long and $2 \mathrm{~mm}$. thick, flesh-colour; perithecia ovate, mouth narrowed, free, crowded; asci cylindrical, slightly capitate, base narrowed into a short, slender pedicel, 8-spored; spores hyaline, arranged in a parallel fascicle in the ascus, filiform, very slender, rather flexuous when free, multiseptate, $65^{-70}$ $x \cdot 8 \mu$, component cells about $3 \mu$ long, not observed to become detached from each other.

On a chrysalis buried among dead leaves. Java (Kurz).

Type specimen in Herb. Kew., examined.

Remarkable for the gregarious habit, 8 plants springing from a weft of mycelium, which spreads over the body of the host. The spores are very slender.

46. Cordyceps acicularis, Ravenel, Journ Linn. Soc. vol. i, p. 159 , pl. i (1857); Sacc., Syll. vol. ii, no. $5 \circ 37$; Ellis and Everh., N. Amer. Pyrenom. p. 64. (Plate II, Figs. 27, 28.)

Cordyceps Carolinensis, Berk. \& Rav. in Rav. Fung. Carol., no. 29.

Exsicc.-Ravenel, Fung. Carol. no. 29. 
Stem simple, elongated, slender, cylindrical, often flexuous or angularly crooked, brown, minutely velvety at the base, glabrous above, $5^{-8} \mathrm{~cm}$. long, $\mathrm{I} \frac{1}{2} \mathrm{~mm}$. thick ; head cylindrical, acute, $\mathrm{I}-\mathrm{I} \frac{1}{2} \mathrm{~cm}$. long, $3 \mathrm{~mm}$. thick ; perithecia blackish, large, ovate, apex truncate and indented, quite superficial and free from each other at the base; asci subcylindrical, elongated, apex capitate, pedicel short, 8-spored; spores arranged in a parallel fascicle in the ascus, hyaline, cylindric-filiform, ends very slightly narrowed, straight or curved, multiseptate, I $30 \times 2.5 \mu$, component cells about $3.5 \mu$ long.

On larvae buried in the ground in damp, shaded woods. S. Carolina (Ravenel, no. 1276). On Nictobates? sp. indet. (Host-Index, p. I8I).

Type specimen in Herb. Kew., examined.

Ravenel's label accompanying the specimen has 'Sphaeria acicularis n. sp.?,' but the specific diagnosis was drawn up by Berkeley, who accepted Ravenel's MS. name.

The apex of the head is not sterile, but as in other species with superficial perithecia, these fall away readily when mature, and had done so from the apex of the head in the specimen described by Berkeley, but in several other specimens of the same species, the head is completely covered with perithecia. Structure of wall of perithecium truly parenchymatous; external cells irregularly polygonal, pale brown, $8-12 \mu$ diameter.

47. Cordyceps falcata, Berk., Decad. Fung. no. 479, in Hook. Journ. Bot. vol. vi, p. 21 I, pl. viii, fig. 2 (1854); Sacc., Syll. ii, no. 5040. (Plate II, Fig. I 5.)

Caespitose; stem $\mathrm{I} \frac{1}{2}-2 \mathrm{~cm}$. long, about $2 \mathrm{~mm}$. thick, equal, even, glabrous; head elongated, narrowly elliptical, apex acute, slightly curved or falcate, about $2 \mathrm{~cm}$. long, and $4 \mathrm{~mm}$. thick at the widest part ; perithecia perfectly superficial, ovate, mouth somewhat narrowed and elongated, crowded; asci cylindrical, apex slightly capitate, base narrowed into a short, slender pedicel, 8 -spored ; spores arranged in a parallel fascicle in the ascus, slightly curved when free, hyaline, filiform, 
multiseptate, $80-90 \times \mathrm{I} \mu$, component cells $4 \mu$ long, readily separating when mature.

On a dead caterpillar. Myrong, Khasia (Hooker and Thompson).

Type specimen in Herb. Kew., examined.

This differs from all known species in the caespitose falcate heads, which are naked at the base on the convex side (Berk., 1. c.).

The head is falcate in all the specimens present in the Herbarium, and if constant, will, as stated by Berkeley, furnish a distinctive feature. The remark that the heads are naked at the base on the convex side, only means in reality that the mature perithecia have fallen away. No mention is made of the colour when fresh, and as the specimens were preserved in spirit, this cannot now be ascertained.

48. Cordyceps Ravenelii, Berk. \& Curtis, Journ. Linn. Soc., vol. i, p. I59, tab. i (1857), (the figures on the plate are not numbered); Sacc., Syll. ii, no. $5 \circ 35$; Ellis and Everh., N. Amer. Pyrenom. p. 62; (Ellis, 1. c., says that a good figure of this species is given in vol. i, p. 9I of Journ. N. Y. Microscop. Soc.).

Torrubia elongata, Riley, is according to Farlow and Seymour-Host-Index, p. I8I-a synonym of the present species. On the other hand, Giard, 1.c., p. 47, considers Riley's species to be identical with C. Melolonthae, Tul.

Exsicc.-Ravenel, Fung. Carol. Exs., Fasc. iv, no. 28.

Stem 3-10 cm. long, $\mathrm{I} \cdot 5-3 \mathrm{~mm}$. thick, almost straight or variously flexuous or crooked, simple or very rarely forked, minutely velvety at first, then almost or quite glabrous, especially upwards, subcylindrical, yellowish-brown, longitudinally wrinkled when dry; head cylindrical, narrowing into the stem at the base, apex more or less acute, $2-5 \mathrm{~mm}$. broad at the widest part, rough with the large, blackish, broadly ovate, perfectly superficial perithecia ; asci elongated, narrowly cylindrical, slightly contracted below the capitate apex, tapering below into a slender pedicel, 8 -spored; spores 
arranged in a parallel fascicle, slightly curved when free, hyaline, linear, multiseptate, $125^{-1} 35 \times 2 \mu$, component cells 4-5 $\mu$ long.

According to Ellis and Everhart, 1.c., this fungus grows on larvae of the 'June beetle' (Lachnosterna fusca) and other larvae (?) buried in the ground. On Anchylonyca, sp. indet. (Host-Index, p. I81).

South Carolina (Ravenel, nos. I 372 and 3080); Texas (Wright, no. 3I55); California (Harkness, no. 1220). There is also a specimen in the Herbarium from Gerard, but without locality, although certainly from the United States. The accompanying label is as follows: "Called the "white grub fungus" in the Western States where found.'

Type in Herb. Kew., examined.

Extremely variable as regards size, some specimens being tall and robust, others extremely slender, and superficially indistinguishable from $C$. acicularis, Rav., the only point of difference furnished by the Kew material being that the spores in the last named are thicker and the component cells slightly shorter than in C. Ravenelii, and it is quite probable that even this character might disappear as such, when a sufficient number of species from different localities come to be examined and compared. The Californian specimens from Harkness-as intimated by Cooke in a note on the labelappears somewhat intermediate between the two species as here understood. Finally, it is only doing justice to the keen perception of Ravenel to state that he suspected more than an affinity between $C$. acicularis and $C$. Ravenelii, as proved by the remark on the label of no. I372 [ $C$. Ravenelii], which reads thus: 'Sphaeria n. sp., spring and summer. On larvae buried in the earth $\mathbf{I}-2$ inches deep. Looks like a variety of $1276^{\prime}[=C$. acicularis $]$;

49. Cordyceps sphingum, Sacc., Mich. i, p. 32 I (1879); Sacc., Syll. ii, no. $5 \circ 33$; Cooke, Veget. Wasps and PlantWorms, p. 127, figs. 27 and 28 ; Ellis and Everh., N. Amer. Pyrenom. p. 64 , pl. xv. 
Torrubia sphingum, Tul., Sel. Fung. Carp., p. 12, pl. i, figs. I-2 (I 865).

(Conidial stage.) Isaria sphingum, Schw., Syn. Fung. Carol., no. I 298 (1822); Cke., Veg. Wasps and Plant-Worms, p. I25, fig. 26.

Isaria sphingophila, Link, Sp. P1., vol. ii, p. I I 4 (1824).

Exsicc.-Fung. Cub. Wrightiani, no. 746 (specimen in the Kew copy shows both conidial and ascigerous conditions).

Parasitic on various moths belonging to the Sphingidae. On some small Orthopterous insect, having the ascigerous fruit well developed; this specimen was collected by Dr. Trail in Brazil, along with other specimens on a Lepidopterous insect. Has been recorded as appearing on the pupa of a Dipterous insect from Scotland.

Distrib. - Britain (conidial form); Switzerland; United States ; Cuba (Wright); St. Domingo ; Brazil (Trail, no. 239 on Orthopterous insect, no. 17 on Lepidopterous insect); Darjeeling (on Spirama retorta and a species of Hypena).

Great confusion exists in herbaria respecting the determination and distribution of the Entomophilous Isariae; everything under the guise of an Isaria parasitic on a moth having been called Isaria sphingum. Unfortunately, this condition of things cannot be satisfactorily remedied from an examination of herbarium material.

50. Cordyceps superficialis, Sacc., Syll. no. $5^{\circ} 3^{6}$; Ellis and Everh., N. Amer. Pyrenom., p. 65 .

Torrubia superficialis, Peck, 28th Rep. N. Y. State Mus. p. 70 (I875).

Under hemlock trees, on buried larvae, Northville, N. Y. (Peck); on Hexapoda, sp. indet. (Host-Index, p. I 82).

Distrib.-United States.

51. Cordyceps memorabilis, Cesati, in Comm. della Soc. Crittog. Ital., vol. i. p. I6 (I86I); Sacc., Syll. ii, no. 5032 .

Racemella memorabilis, Cesati, Comm. della Soc. Crittog. Ital. vol. i, p. 65, pl. iv, fig. I. 
Growing on a beetle-Staphylimus sp.

Distrib.-Oropa, N. Italy.

\section{$\dagger+$ Spores continuous.}

52. Cordyceps isarioides, Curtis, MS. (Plate II, Figs. 36-39.)

Gregarious, springing from a dense white mycelium which almost entirely covers the host; stem $4^{-8} \mathrm{~mm}$. high, about I.5 mm. thick, cylindrical, almost glabrous, even, ochraceous (when dry), sometimes slightly curved; head 3-6 mm. long, cylindrical, obtuse, axial portion not thicker than the stem; perithecia perfectly superficial, large, flask-shaped, mouth elongated, ochraceous, crowded, spreading on all sides at right angles to the axis; asci narrowly cylindrical, slightly capitate, base narrowed into a slender pedicel, 8-spored; spores cylindric-filiform, continuous, flexuous when free, hyaline, I $25^{-I} 35 \times \mathrm{I} \cdot 5 \mu$, arranged in a parallel fascicle in the ascus.

Growing from the remains of a moth. Owing to an unfortunate mistake this species is represented growing on a chrysalis. Curtis, no. 6521. No locality given, but undoubtedly from the United States.

The type specimen is in Herb. Kew.

The specimens, along with numerous other packets that had never been examined by Berkeley, were sent to Kew after his death. The present differs from other known species of Cordyceps with free perithecia in the spores being continuous, and as they escaped from the ascus readily when placed in water, it may be assumed that they were mature, and not likely to become multiseptate. In the filiform continuous spores, the species agrees with the genus Claviceps, but differs in developing on an insect, and forming a sclerotium in its anterior.

\section{Species imperfectly described.}

53. Cordyceps Sinclairi, Berk., Flora Nov. Zel., p. $33^{8}$ (1855); Berk., Intr. Crypt. Bot., p. 73, fig. I7 ; Sacc., Syll. ii, no. $5 \circ 54$. 
Torrubia caespitosa, Tulasne, Carpol. iii, p. I I (I865).

Cordyceps caespitosa, Sacc., Syll., no. 5043.

Yellowish, from $\frac{3}{4}-1$ in. high; stems cylindrical, slender, simple or forked, sometimes confluent, $\frac{1}{2}$ inch or more high, divided above into numerous more or less cylindrical, either simply or slightly lobed heads, which are sometimes disposed into a flabelliform mass, clothed with innumerable oblong conidia $\frac{1}{3500}$ of an inch long.

The specimens are unfortunately destitute of perithecia. The pale yellowish tint, inclining to lemon colour, seems characteristic, and forbids, in the first instance, their union with Cordyceps sobolifera, a West Indian species, which also occurs on Orthopterous larvae. In that species, however, the normal form seems to be simply clavate, as in Cordyceps entomorrhiza, and the divisions are merely proliferous. There does not seem, in the present case, to be any indication of such a primitive form, and, in consequence, I suppose the head to be essentially divided, as in Cordyceps Taylori. I have therefore no hesitation in considering it distinct, more especially as the West Indian species is a purely tropical form, and does not ascend as far as the Southern United States, which produce some New Zealand species, but is represented by an allied form still normally simple on the larvae of cockchafers.

Northern Island [New Zealand]; on the larvae of some Orthopterous insect, amongst loose gravelly soil, in the garden of Archdeacon Williams, Tauranga, Poverty Bay.

The above is Berkeley's original account of the species, which unfortunately I am unable to supplement, the species not being present in the Herbarium in a mature condition. Tulasne's species, Torrubia caespitosa, was received from the same locality as the above species, with which it is obviousiy synonymous.

54. Cordyceps Melolonthae, Sacc., Mich. i, p. 320 (1879); Sacc., Syll. ii, no. 5044 ; Ellis and Everh., N. Amer. Pyrenom. p. 66. 
Torrubia melolonthae, Tulasne, Sel. Fung. Carpol. iii, p. I2 (1865); Torrubia elongata, Riley. According to Giard, 1.c. p. 47 , this is a synonym of the present species.

On buried larvae of the 'May bug' Lachnosterna fusca; on larvae of Ancyloncha puncticollis (fide Gray).

Distrib.--Pennsylvania, United States.

A figure is given in Silliman's Journ. vol. viii, pl. iv (1824), giving the general appearance of this species springing from the cervical region of the buried larva of the May bug.

55. Cordyceps coccigena, Sacc., Mich. i, p. 320 (1879); Sacc., Syll. ii, no. 5047 .

Torrubia coccigena, Tul., Sel. Fung. Carpol. iii, p. 19, t. I, fig. Io (I865).

Growing on some Coccus.

Distrib.-Dory, New Guinea (Dumont d'Urville).

56. Cordyceps gigantea (Mont.).

Isaria gigantea, Montag., Syll. no. 1079 (1856); Mont., Cub. p. 309.

Cordyceps Montagnei, Berk. \& Curt., Fungi Cuben. no. 747, in Linn. Soc. Journ., Bot., vol. x, p. 375 (1869).

On the body and feet of Mygale cubana, Walker.

Distrib.-Cuba (Ramon de la Sagra).

The conidial form is alone known at present. Montagne's original specific name has been restored.

57. Cordyceps cicadae (Miq.).

Isaria cicadae, Miquel, Bull. Sci. Phys. et Nat. Néerl. vol. i, p. 85 , tab. i, fig. $A$ (1838).

Torrubia Miquelii, Tul., Carpol. iii, p. I I (I 865).

Cordyceps Miquelii, Sacc., Mich. i, p. 320 (1879); Sacc., Syll. ii, no. 5046 .

On larva of Cicada. Saccardo says also on some lamellicorn insect in the United States.

Distrib.-Brazil.

Miquel's original specific name has been rcstored.

58. Cordyceps Mawleyi, J. O. Westwood, Gard. Chron. May 2, 189 I, p. 553, fig. II 5, p. 563 :- 
'We describe and figure an interesting example, being the underground caterpillar of a British Noctua, or possibly Hepialus, of which we received specimens from E. Mawley, Esq., of Rosebank, Berkhampstead, Herts. Several similar specimens were found underground in a border of herbaceous perennials, near a good sized lime-tree; they were all found dead, each with a profusion of filaments from the segments behind the head, which appear to have been injured or crushed. They were generally found about $\mathrm{I}$ inch below the surface, and the fungoid filaments sometimes emerge from each end of the caterpillar, one being seen in the figure near the extremity of the body. The species may be named after its discoverer Cordyceps Mawleyi. J. O. Westwood.'

It can scarcely be hoped to recognize in future the object the author had in view. The figure shows a caterpillar with a mass of Isaria-like filaments and a single, slender, flexuous club about $2.5 \mathrm{~cm}$. long.

59. Cordyceps albella (Berk. \& Curt.).

Numerous slender stems spring from the under surface of the thorax and abdomen of the host, whitish or tinged yellow, $\frac{\mathrm{I}}{2}-\mathrm{I} \mathrm{cm}$. long, $\mathrm{I}-2 \mathrm{~mm}$. thick, cylindrical or with an indication of becoming clavate, all immature. The body and legs of the insect are almost covered with a whitish mould.

Cordyceps albidus, Berk. \& Curtis, in Herb. The specific name is antedated by Patouillard.

On the perfect form of a member of the Gryllidae.

Cuba (Wright, no. 890).

Apparently the same species-sterile-growing on some Orthopterous insect, was sent from Ceylon by Thwaites.

60. Cordyceps fuliginosa, Cesati, Giorn. Inst. Lomb. Milan, I 848, p. 31 ; Comm. Crittog. Ital. vol. i, p. 67, t. 6, fig. I ( I 861); Sacc., Syll. ii, no. 5042 ; Cke., Veget. Wasps and Plant Worms, p. 183 , pl. i, fig. 5 (after Cesati).

On Bombyx (Orgyia) antiqua.

Distrib.-Italy. 
61. Cordyceps ? adpropinquans, Sacc., Syll. ii, no. $5 \circ 56$.

Torrubia adpropinquans, Cesati, Myc. Born., in Mem. Acad. Neapol. (1879).

Host unknown.

Distrib. Sarawak, Borneo.

62. Cordyceps Humberti, Robin, in Tul., Carpol. iii, p. 18 ; Sacc., Syll. no. 5045 .

On a wasp-Icaria cincta.

Distrib.-Senegal.

\section{Excluded Species.}

Cordyceps setulosa, Quél., Champ. Jura et Vosges, p. 48;, t. 4 , fig. 4 .

A true species of Claviceps. Described as having a sclerotium and springing from the fruit of a species of Poa.

Cordyceps racemosa, Berk., Dec. Fung. no. 480, in Hook., Journ. Bot., p. 2 II, pl. viii, fig. 3 (I 854 ); Sacc., Syll. ii, no. 5049 .

This proves, on examination, to be a species of Balanophora, and is described by Hemsley as Balanophora Hookeriana.

Berkeley evidenly suspected something of the kind, as he says, 'Except for its place of growth it might easily be passed over as an imperfect Balanophora.' Its being in contact with a caterpillar is probably quite accidental. 


\section{INDEX OF SPECIES.}

(Synonyms are printed in italics.)

\section{Balanophora Hookeriana, 40.}

\section{Clavaria, $3 \circ$.}

- militaris, 30.

- sobolifera, I3.

Claviceps, $6,9,36,40$.

Corallomyces, 7,9 .

Cordyceps, I, passim, 9.

- acicularis, 3 I, 34 .

- adpropinquans, 40.

- albella, 39 .

- albida, 27.

- albidus, 39.

- alutacea, I3.

- armeniaca, 8, 23.

- australis, I 5 .

- Barberi, I8.

- Barnesii, Io, I I.

- bicephala, 2 I.

- Bovellii, 18.

- caespitosa, 37.

- caloceroides, 23.

- Carolinensis, 3I.

- cicadae, 38.

- cinerea, I5.

- coccigena, $3^{8}$.

- clavulata, 8, 22.

- curculionum, I4.

- dipterigena, 20.

- Ditmari, I6.

- Doassansii, 27.

- entomorrhiza, 6, 8, 25, 37 .

- falcata, 32.

- flavella, 19.

- Forquingnoni, I 7 .

- fuliginosa, 39 .

- gentilis, I7.

- gigantea, 38 .

- goniophora, I5.

- gracilis, 25

- Gunnii, I8.

- Hawkesii, I7.

- Helopis, 16.

- Henleyae, 28.

- herculea, 26.

- Humberti, 40.

- Hugelii, 30

- var. neglecta, 30.

- insignis, I 2.

- isarioides, 36.

- Langloisii, 26

- larvicola, I6.

- Lloydii, 20.

- martialis, I 5 .
Cordyceps, Mawleyii, $3^{8 .}$

- melolonthae, 33, 37 .

- memorabilis, 35 .

- menesteridis, $25,26$.

- militaris, 2, 4, 8, 30 .

- Miquelii, $3^{8}$.

- Montagnei, 38 .

- myrmecophila, 8, I4.

- nutans, 26.

- Odyneri, 26.

- palustris, II.

- pistillariaeformis, 22.

- Puiggarii, I3.

- racemosa, 40.

- Ravenelii, 33, 34.

- Robertsii, 30 .

- setulosa, 40.

- Sherringii, 27.

- Sinclairi, 36 .

- sinensis, 24.

- sobolifera, I I, I3, 37 .

- sphaecocephala, 13 .

- sphaecophila, I 3 .

- sphingum, 8, 34 .

- stylophora, 16.

- superficialis, 35 .

- Taylori, 27, 37.

- typhulaeformis, $3 \mathbf{I}$.

- unilateralis, I 5 .

- velutipes, 2 I.

- Wallaysii, I 5.

Cordylia, 7, 9, 10.

Epichlöe, 6.

Hypocrea, 6, I3.

Isaria, 4, 5, 7 .

- Barberi, I8.

- cicadae, $3^{8}$.

- densa, $5,6$.

- farinosa, 4, 5, 6, 30 .

- fuciformis, 6 .

- gigantea, 38 .

- sphecophila, 16.

- sphingophila, 35.

- sphingum, 35.

Racemella, memorabilis, 35 .

Ramaria, farinosa, 30.

Sphaeria, 4.

- clavulata, 22.

- entomorrhiza, 25. 
Sphaeria, herculea, 26.

- Hugelii, 3 o.

- innominata, 27.

- Robertsii, 30.

- sinensis, 24.

- sobolifera, I3.

- sphaecocephala, I4.

- Taylori, 27.

Torrubia, IO.

- adpropinquans, 40.

- caespitosa, 37.

- cinerea, I5, 22.

- clavulata, 22.

- coccigena, $3^{8}$.

- curculionum, 14.
Torrubia, elongata, $33,3^{8 .}$.

- entomorrhiza, 25.

- gentilis, I7.

- melolonthae, 37.

- Miquelii, $3^{8 .}$

- militaris, 4 , 30.

- pistillariaeformis, 22.

- sobolifera, I3, 37 .

- sphecocephala, I4.

- sphingum, 35 .

- superficialis, 35.

- unilateralis, I5.

Xylaria, IO, 2 I.

- gracilis, 25.

Xylodactyla, 2 I.

\section{INDEX OF HOSTS.}

Anchylonyca, 34.

Anchylonyca puncticollis, $3^{8 .}$

Ant, I 5, 20, 27.

Atta cephalotus, I 5.

Bombyx antiqua, 39 .

Camptonotus atriceps, 20.

Carabus, I 5 .

Cerambicidae, $\mathbf{I} 5$.

Cicada, $3^{8}$.

Coccus, 38 .

Cockchafer, 5, 37 .

Coleoptera, 7, I 2, I 4, 23.

Cossus, I9.

Dasyphora pratorum, I 7 .

Diatraea saccharalis, $\mathbf{I} 8$.

Diptera, 7, 20, 35 .

Elateridae, 22.

Flies, I6.

Formica rufa, I 4.

Gastrophaca, 3I.

Gortyna, 24.

Gryllidae, 39.

Heilipus celsus, I 4 .

Helops caraboides, I6.

Hemiptera, 7, 26.

Hepialus, 19, 29, 30, 39.

- virescens, 30.

Hexapoda, I 2, I 7, 26, 35 .

Hymenoptera, $7,14$.

Hypena, 35 .

Icaria cincta, 40 .
Lachnosterna quercina, 30 .

- fusca, 34, 38 .

Lecanium, 22.

Lepidoptera, $7,27,30,35$.

Lithoosidae, 26.

Mason-wasp, 26.

Melolontha vulgaris, 26, $3 \mathrm{I}$.

Melolonthidae, I I, I3.

Menesteris laticollis, 26.

Moth-borer, 18.

Musca rufa, I7.

Mutilla, I6.

Mygale cubana, $3^{8}$.

Nictobates, 32 .

Noctua, 39 .

Noctuidae, 24.

Notodontidae, 30.

Odynera, 27 .

Orthoptera, 35 .

Pachycondyla striata, I5.

Phalera bucephala, 30 .

Pielus, 17.

Polybia, I4.

Silphidae, 25.

Sphingidae, 35 .

Spirama retorta, 35 .

Staphylinus, 36 .

Tinea, 26.

Vespa, I4.

Wasp, I4, I6, I7, 40 . 


\section{EXPLANATION OF FIGURES IN PLATES I AND II.}

Illustrating Mr. Massee's paper on Cordyceps.

\section{PLATE I.}

Fig. I. Cordyceps Henleyae, Mass., growing from the head of a caterpillar. Nat. size.

Fig. 2. Section of portion of a fertile branch, showing the superficial perithecia. $\times 20$.

Fig. 3. Asci in different stages of development. $\quad \times 750$.

Fig. 4. Apex of an ascus, showing the arrangement for effecting dehiscence. $\times$ I 200.

Fig. 5. Spore as appearing when placed in water. $\times 750$.

Fig. 6. Spore as appearing when treated with very dilute potassic hydrate. $\times 750$.

Fig. 7. Portion of Fig. 5, more highly $x$.

Fig. 8. Portion of Fig. 6 , more highly $x$.

Fig. 9. Portion of a mature spore breaking up into its component cells. $\times 750$. Fig. Io. One of the component cells of a spore germinating. $\quad \times$ I 200 .

Fig. II. Transverse section through a segment of the caterpillar serving as host to the fungus, showing the interior to be completely filled with densely interwoven hyphae, and forming a hard, compact mass when dry. $\quad \times 2$.

Fig. I 2. Portion of the hyphae filling the body of the host-caterpillar. $\times 75^{\circ}$.

\section{PLATE II.}

Fig. I. Cordyceps palustris, Berk. Nat. size.

Fig. 2. Section of portion of head of same, showing the perithecia. $\times 50$.

Fig. 3. Ascus of the same. $\times 35^{\circ}$.

Fig. 4. Spore of same. $\times 35^{\circ}$.

Fig. 5. Portion of spore in young stage, with oil-globules. $\times 75^{\circ}$.

Fig. 6. Portion of mature spore, showing transverse septa. $\times 75^{\circ}$.

Fig. 7. Cordyceps flavella, Berk. and Curtis; group of Fungi growing from portion of a caterpillar. Nat. size.

Fig. 8. Section of portion of head of same, showing the perithecia. $\times 50$.

Fig. 9. Ascus. $\times 35^{\circ}$.

Fig. 10. Spore. $\times 35^{\circ}$.

Fig. II. Cordyceps caloceroides, Berk. and Curtis. Nat. size.

Fig. I 2. Section of a superficial perithecium and portion of stroma of same, showing the true parenchymatous structure of the tissue. $\times 5_{50}$.

Fig. I3. Spore of same. $\times 35^{\circ}$. 
Fig. 14. Cordyceps typhulaeformis, Berk. and Cooke. Nat. size.

Fig. I5. Cordyceps falcata, Berk. Nat. size.

Fig. I6. Cordyceps bicephala, Berk. Nat. size.

Fig. I7. Cordyceps sinensis, Berk. Nat. size.

Fig. I 8. Cordyceps armeniaca, Berk. Nat. size.

Fig. 19. Cordyceps Barnesii, Thwaites. Nat. size.

Fig. 20. Section of a superficial perithecium and portion of stroma of same, showing the whole to be composed of densely interwoven hyphae. $\times$ I 50 .

Fig. 2 I. Spore. $\times 350$.

Fig. 22. Spore broken up spontaneously into its four component cells. $\times 35^{\circ}$.

Fig. 23. Conidia bearing condition of Cordyceps Barnesii. Nat. size.

Fig. 24. Branched conidiophores of same. $\times 80$.

Fig. 25 . Single head of conidia. $\times 35^{\circ}$.

Fig. 26. Fertile hyphae forming the head, each bearing a chain of conidia at its apex. $\quad \times 750$.

Fig. 27. Cordyceps acicularis, Ravenel. Nat. size.

Fig. 28. Spore of same. $\times 35^{\circ}$.

Fig. 29. Cordyceps dipterigena, Berk. and Broome. Nat. size.

Fig. 30. Section of portion of head of same, showing the completely immersed perithecia. $\times 50$.

Fig. 3I. Portion of ascus of same, showing the spores broken up into their component cells. $\times 600$.

Fig. 32. Component cells of spore of same. $\quad \times 600$.

Fig. 33. Cordyceps Hugelii, var. neglecta, Mass. Nat. size.

Fig. 34. Cordyceps Barberi, Giard, growing on the larva of Diatraea saccharalis, Fabr., lying in its burrow in a piece of sugar-cane. Nat. size.

Fig. 35. Ascus of same. $\times 35^{\circ}$.

Fig. 36. Cordyceps isarioides, Curtis. Nat. size.

Fig. 37. Head of same. $\times \mathbf{2 5}$.

Fig. $3^{8}$. Portion of ascus of same, showing the spores in the act of becoming free. $\times 400$.

Fig. 39. Free spore of same. $\times 400$.

Fig. 40. Cordyceps stylophora, B. and Br. Nat. size.

Fig. 4 I. Head of same. $\times 5$.

Fig. $4^{2}$. Spore of same. $\times 350$. 
Annats of Botany

Vol.IX, PL.I.

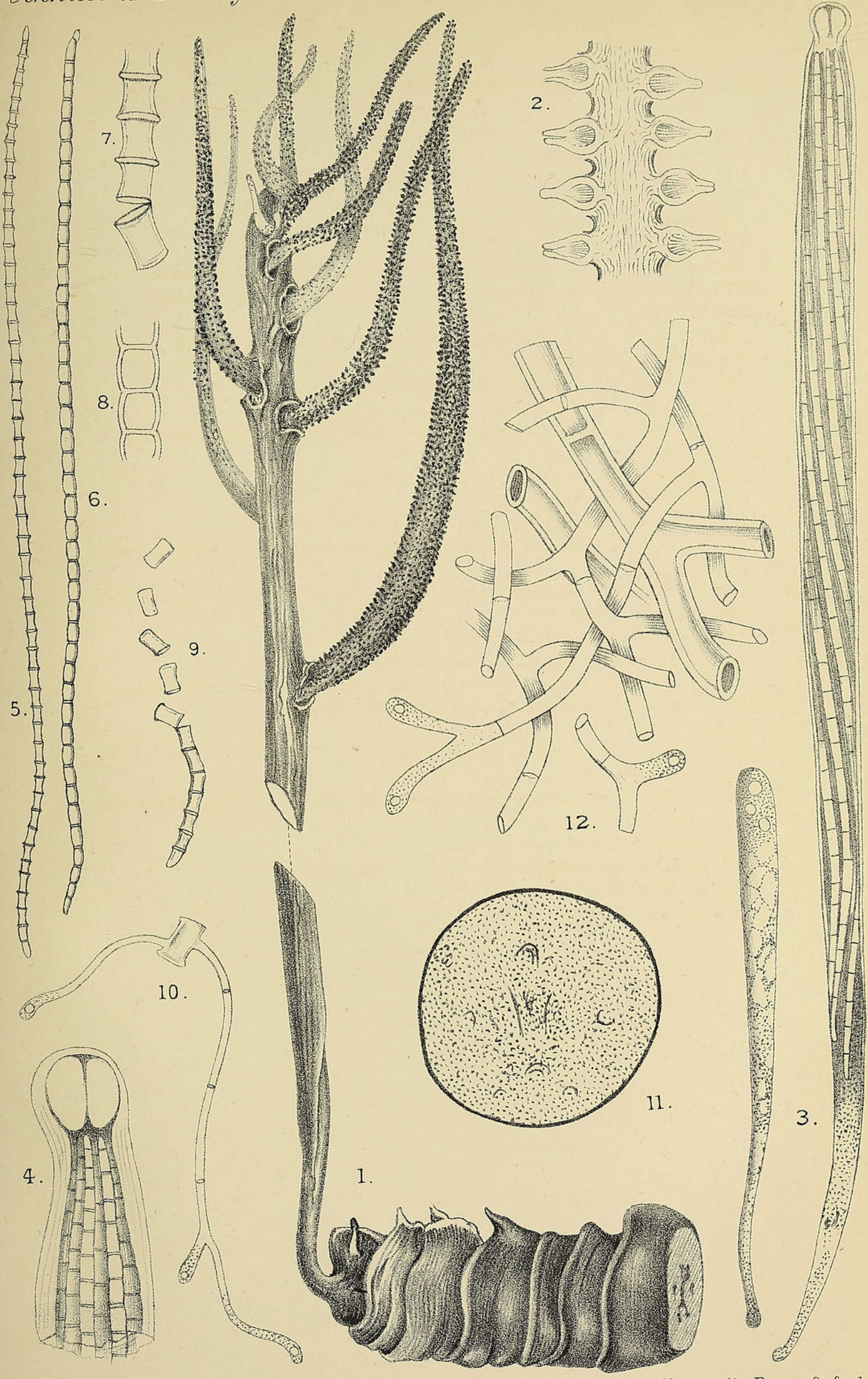

G. Massee del. 
Annats of Botany
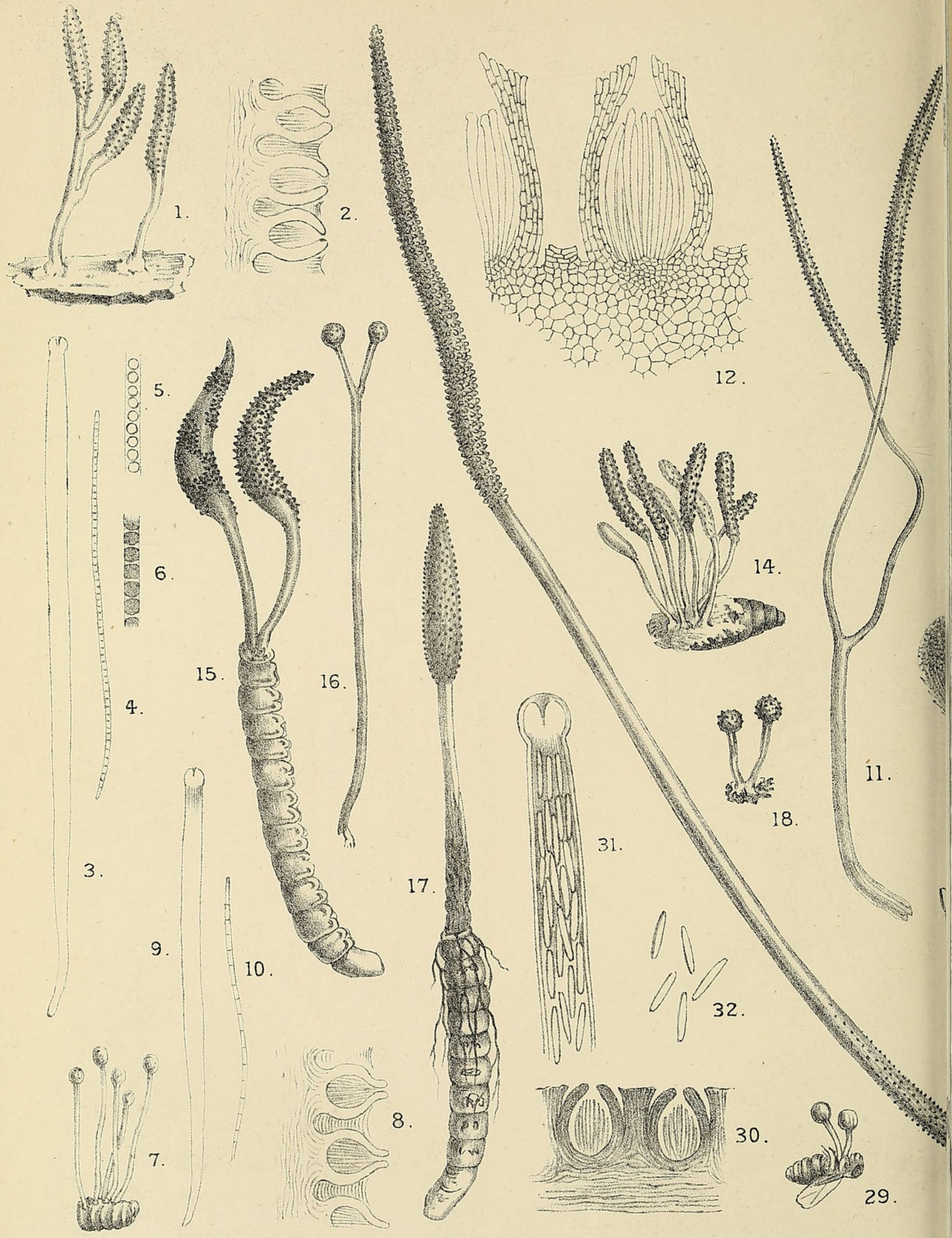

G. Massee del.

$$
\text { MASSEE - CORDYCEPS. }
$$


VoL.IX, PLIII.
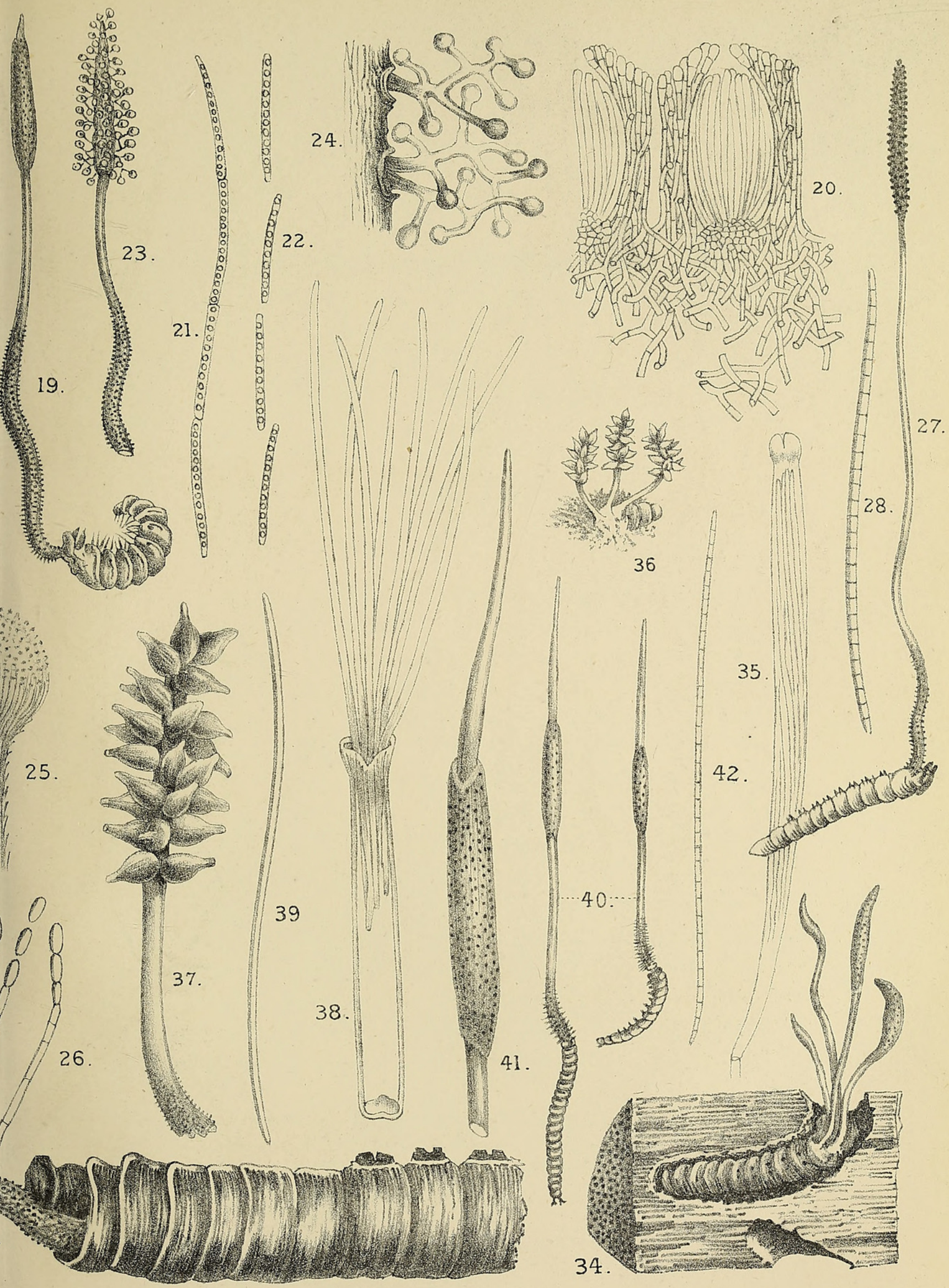

University Press, 0xford. 

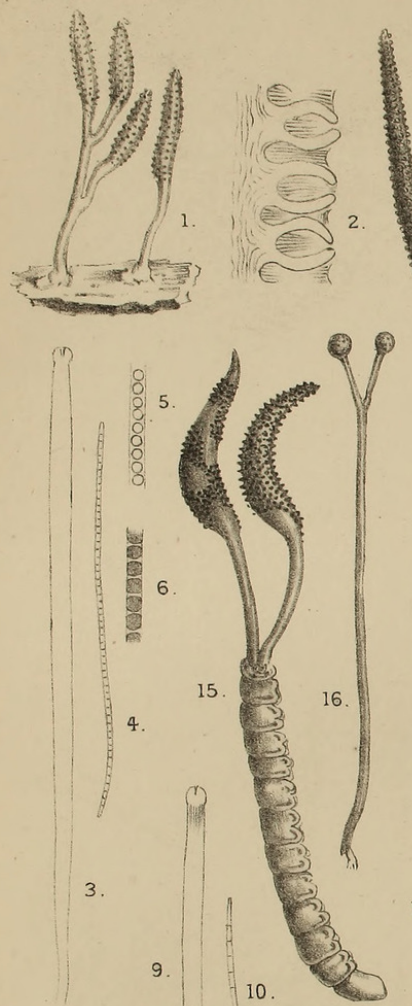

$p^{9} p^{9}$ (tillo G. Massee del.
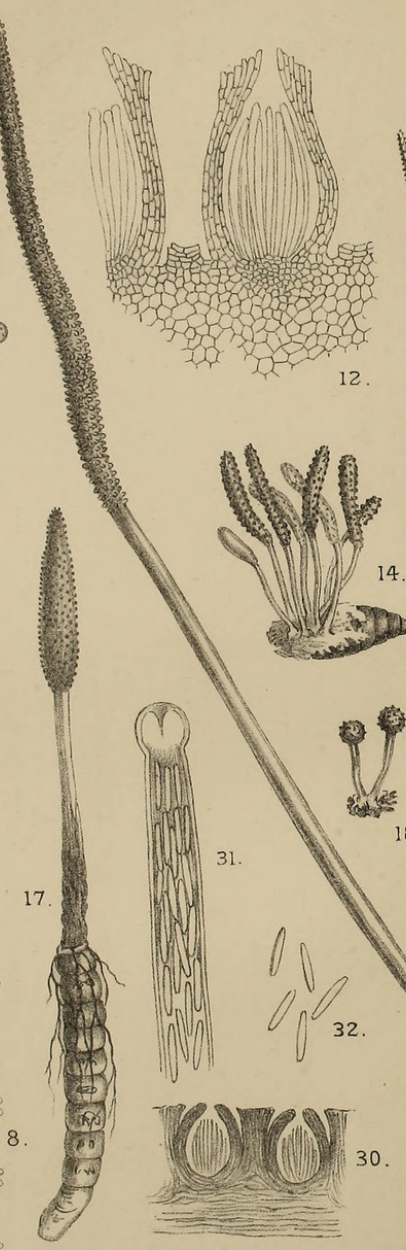
1.

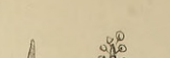

Vol.IX, PLIII. 


\section{$2 \mathrm{BHL}$ Biodiversity Heritage Library}

Massee, George. 1895. "A revision of the genus Cordyceps." Annals of botany 9, 1-44. https://doi.org/10.1093/oxfordjournals.aob.a090724.

View This Item Online: https://www.biodiversitylibrary.org/item/233478

DOI: https://doi.org/10.1093/oxfordjournals.aob.a090724

Permalink: https://www.biodiversitylibrary.org/partpdf/318364

\section{Holding Institution}

Smithsonian Libraries

\section{Sponsored by}

Biodiversity Heritage Library

\section{Copyright \& Reuse}

Copyright Status: Not in copyright. The BHL knows of no copyright restrictions on this item.

This document was created from content at the Biodiversity Heritage Library, the world's largest open access digital library for biodiversity literature and archives. Visit BHL at https://www.biodiversitylibrary.org. 